ANADOLU, J. of AARI

ISSN: 1300-0225 (Print)

E-ISSN: 2667-6087 (Online)

2020, $30(1): 11-32$

DOI: 10.18615/anadolu.727146

\title{
Kars İlinde Sebze Olarak Tüketilen Yabani Bitki Türlerinin Tespiti ve Kullanım Şekilleri
}

\author{
Zakine Kadıoğlu ${ }^{1}$ \\ N. Nazan Kalkan ${ }^{4}$ \\ Kemal Çukadar ${ }^{2}$ \\ Ali Kandemir ${ }^{3}$ \\ Hüseyin Vurgun ${ }^{5}$ \\ Veysel Dönderalp ${ }^{6}$ \\ 1, 2, 4, 5, ${ }^{6}$ Erzincan Bahçe Kültürleri Araştırma Enstitüsü Müdürlüğ̈̈, Erzincan/TURKEY \\ ${ }^{3}$ Erzincan Binali Yıldırım Üniversitesi Fen-Edebiyat Fakültesi, Biyoloji Bölümü, Erzincan/TURKEY \\ ${ }^{1}$ https://orcid.org/0000-0003-2727-6771 \\ ${ }^{3}$ https://orcid.org/0000-0003-1902-9631 \\ ${ }^{5}$ https://orcid.org/0000-0001-5871-8873 \\ ${ }^{2}$ https://orcid.org/0000-0003-1395-0964 \\ ${ }^{4}$ https://orcid.org/0000-0002-9204-7281 \\ ${ }^{6}$ https://orcid.org/0000-0001-5517-4364 \\ *Corresponding author (Sorumlu yazar): zakin_e@hotmail.com \\ Received (Geliş tarihi): 15.05.2019 Accepted (Kabul tarihi): 14.01.2020
}

\begin{abstract}
ÖZ: Bu çalıșma, 2015-2016 yıllarında Kars ili, ilçe ve köylerinde yaşayan yöre halkı tarafindan sebze olarak kullanılan bitki türlerini tespit etmek, belirlenen türlerin kullanım şekilleri ile ilgili kültürel zenginliklerimizi belirleyerek, gelecek nesillere aktarmak amacı ile gerçekleştirilmiştir. Araş̧ırma alanındaki 19 familyaya ait toplam 87 taksonun, sebze olarak kullanıldı̆̆ belirlenmiştir. Tespit edilen bu bitki türlerinin daha çok Asteracea, Lamiaceae, Polygonacea ve Apiaceae familyalarına ait olduğu görülmüştür. Bu bitkilerin, kök, gövde, sürgün, çiçek, dal, yaprak, tohum ve yumru gibi kısımlarının sebze olarak tüketildiği belirlenmiş ancak, bitkinin yenilen kısımlarının yöreden yöreye farklılık gösterdiği tespit edilmiştir. Yöre halkının bu bitki türlerini taze olarak, kurutarak, salamura ederek, turşuya işleyerek, dondurarak veya konserve şeklinde muhafaza ederek uzun sürede tükettiği belirlenmiştir. Ayrica bu bitki türlerini; çĭ̆ (salata), yemek, sarma, çorba, börek içi, turşu, reçel olarak değerlendirdiklerini, bazıların ise baharat olarak, tat ve koku vermek için, çay olarak ve tedavi amacı ile de kullandıkları tespit edilmiştir. Toplanan bitkilerin yöresel adları, bulunduğu yerin konumu, bitkinin kullanılan kısımları, kullanım şekilleri ögrenilerek kayıt altına alınmıştır. Bitkilere ait herbaryumları hazırlanarak teşhisleri Erzincan Binali Yıldırım Ünüversitesi Fen Fakültesi Biyoloji Bölümü'nde yapılmıştır. Herbaryum örnekleri ve alınan tohum örnekleri muhafaza amacı ile Türkiye Tohum Gen Bankası (Ankara) ve Ulusal Tohum Gen Bankası'na (Menemen/İzmir) gönderilmiştir.
\end{abstract}

Anahtar Kelimeler: Kars, sebze, yabani bitkiler, tüketim şekilleri.

\section{Determination of Wild Plant Species Consumed as Vegetables and Their Types of Usage in Kars Province}

\begin{abstract}
This study was carried out to specify the plant species consumed as vegetables by local people living in districts and villages of Kars province in order to determine our cultural richness based on the usage types of these species by aiming to hand down the next generations in 2015-2016. It was determined that 87 taxa belonging to 19 families are used as vegetables in the research area. It was found that determined plant species belong to Asteracea, Lamiaceae, Polyogonocea and Apiaceae families. While it was determined that parts of these plants such as root, stem, shoot, flower, branch, leaf, seed and tuber were consumed as vegetables, however, it was also revealed that the habit of consuming may be differed from region to region. These plants are consumed as fresh, dried, in brine, frozen, processed by pickles or preserved in the form of canned food. Moreover, it was ascertained that they are consumed as raw (salad), food, wrap, soup, pastry, pickles, jams and some of them as spices for taste and smell, and additionally as tea for therapeutic purposes. All plants were recorded by their local names, locations, parts with their usage patterns. Herbarium was prepared and later identified by Department of Biology, Faculty of Science, Erzincan Binali Yildirim University. Herbarium specimens and seed samples were sent to Seed Gene Bank of Turkey (Ankara) and the National Seed Gene Bank (Menemen/İzmir) by aim of conservation.
\end{abstract}

Keywords: Kars, vegetable, wild plants, types of consuming. 


\section{GİRIŞ}

Türkiye, 174 familyaya ait 1251 cins ve 12.000'den fazla tür ve türaltı taksonu (alt tür ve varyete) ile oldukça zengin bir floraya sahiptir (Davis, 1965-1985; Güner ve ark., 2000). Tüm Avrupa kıtasının yaklaşık 12.000 kadar bitki taksonuna sahip olduğu düşünüldüğünde yurdumuzun bitki örtüsü bakımından nedenli zengin olduğu görülmektedir (Ekim ve ark., 2000). Endemizm bakımından da yurdumuz oldukça zengindir. Tüm Avrupa ülkelerindeki toplam endemik takson sayısı yaklasık 2750 iken ülkemizdeki endemik tür sayısı 2891, endemik takson sayıs1 3750'den fazladır (Güner ve ark., 2000). Bütün bu bilgiler göz önüne alındığı zaman, ülkemizin bu konuda büyük bir çalışma potansiyeline sahip olduğu görülmektedir. Ayrıca bilimsel verilerin halkla bütünleşebilmesi için yerel bitki adlarının da tespit edilerek güncelleștirilmesi gerekir. Bu konu da yine, etnobotanik çalışmaların önemli bir parçasını oluşturmaktadır (Kendir ve Güvenç, 2000).

Doğu Anadolu Bölgesi yaklaşık 170 bin km²'lik bir alan ile ülkemizin \%20'lik bir kısmını kaplar ve yüzölçümü açısından en büyük bölgemizdir. 14 ilin yer aldığı bölge; Irak, İran, Nahcivan, Ermenistan ve Gürcistan ülkeleri ile sınır oluşturur ve İran Turan fitocoğrafik bölgesinde yer alır. 3000 üzerinde bitki türüne sahip bölge $\% 25^{\prime}$ lik oranla endemizm açısından ülkemizin en zengin bölgelerinin başında gelmektedir. Bölgenin coğrafi koşulları, köylerin şehir merkezlerine olan uzaklığı, soğuk ve uzun geçen kış ayları sebebiyle bitkilerle tedavi günümüzde dahi oldukça yaygındır (Altundağ ve Öztürk, 2011).

Bitkilerin faydalı etkileri bileşimlerinde bulunan çeşitli kimyasallara bağlı olarak değişiklik göstermektedir. Doğal ortama, zorlu yaşam koşullarına uyum sağlamış yabani bitki çeşitliliğinin korunması, ileriki dönemlerde bitki yetiştiriciliği konusundaki karşlaşılabilecek zorluklara karşı bir sigorta görevi görmektedir. Kültürü yapılan bitkiler üzerindeki genetik araştırmalar, yoğun kimyasal gübre ve ilaç kullanımı, ürünlerin doğal lezzet ve kendine has güzel kokularını kaybetmesi, muhtemel sağlık riskleri ve daha birçok sebepten dolayı son yıllarda organik ürünlere ve yabani bitkilere olan ilginin artmasına neden olmuştur. Aynı zamanda doğal ortamda yetişen ve herhangi bir insan müdahalesine maruz kalmayan bu bitkilerin tıbbi etkileri de kullanım alanlarını cazip hale getirilmiştir (Şekeroğlu ve ark., 2005).

İlk çağlardan günümüze değin insanoğlu kendi yöresinde bulunan bitkilerden farklı amaçlarla, çeşitli şekillerde yararlanmıştır. Önceleri doğadan topladıkları yabani bitkileri kullanmış, sonraları en çok kullandıklarının tarımını yapmışlardır. Ülkemiz zengin bir flora ve kültür mirasına sahip olmasına rağmen Anadolu'da yabani bitkilerin halk arasındaki tedavi, gıda ve diğer amaçlarla kullanılışını konu alan bilimsel nitelikteki çalışmalar hızla artmıştır. Anadolu'nun biyokültürel çeşitliliği ve etnobotanik mirasına yönelik çalışmalar özetlenmiş (Ertuğ, 2014a) ve Anadolu'da yenen bitki türleri listelenmiştir (Ertuğ, 2014b).

Yaşamımızda yer alan bitkilerin tanımlanabilmesi için her birine özel adlar verilerek sözlü ve yazılı kaynaklar ile bu adların nesilden nesile aktarılması sağlanmıştır. Bitkileri tanıma ve adlandırma bilgisinin altında öncelikli olarak bitkilerden yararlanma veya zararından korunma eğiliminin olduğu bilinmektedir (Alkayış, 2007; Baytop, 2007; Tuzlacı, 2011). Bir bölgedeki bitkilerin yöresel isim bilgisine bakıldığında adlandırılan bitkilerin çoğunun gıda, baharat, barınma, ilaç, boya, süs, kozmetik, yakacak, eşya, hayvan yemi veya hayvan hastalıklarında kullanımı olan bitkiler olduğu görülmektedir (Baytop, 2007; Tuzlac1, 2011; Ertuğ, 2014b).

Doğu Anadolu Bölgesinde gerçekleştirilen etnobotanik taramalar sonucu, bölgede yayılış, gösteren bazı tıbbi bitkiler tespit edilmiştir. Değişik ekolojik durumlar, farklı iklimsel tipler ve vejetasyon geçmişinden dolayı Doğu Anadolu Bölgesi'nin zengin bir floraya sahip olduğunu bildirmişlerdir (Özgökçe ve Özçelik 2004). Zengin bir kültürel mirasa sahip olan Kars ilinde etnobotanik açıdan oldukça kapsamlı bir bilgi hazinesi mevcuttur ancak, kirsal kesimden kentlere olan göçlere ve gelişen teknolojiye paralel olarak, yeni nesiller bu hazinenin değerini bilememekte ve kaybolma riski taşımaktadır. $\mathrm{Bu}$ nedenle bu bitkilerle olan kültürümüze ait bilgilerin bir an önce yazılı hale getirilme zorunluluğu ortaya 
çıkmaktadır. $\mathrm{Bu}$ zorunluluk ülkemiz ekonomisi açısından da önemlidir. Hangi bölgelerde hangi bitkilerden yararlanılabileceğinin tespiti ancak etnobotanik çalışmalar ışı̆̆ında belirlenebilecektir. Böylece halktan alınan bilgiler halkın ekonomisine katkı sağlaması için geri dönecektir.

Güvenç ve Kaya (1996), Erzurum'da sebze olarak değerlendirilen yöresel türleri tespit etmek amac1 ile yürüttükleri çalışmada, bağa yaprağı (Plantago major), 1sırgan (Urtica dioica), mananık (Sinapis arvensis), kuzukulağ (Prangos uechritzii), 1şgın (Rheum ribes), çiriş (Asphodelus ramosus), kuşekmeği (Polygonum aviculare), yarpuz (mentha pulegium), pirpirim (Portulaca oleracea) çaşır mantarı (Pleurotus eryngii), çayır mantarı (Agaricus campestris) gibi türleri belirlemişler ve bunların genellikle pişirilerek tüketildiğini bildirmişlerdir.

İyigün ve Özer (2001), Muş ili ve yöresinde gıda olarak tüketilen yabancı otları araştırmak amacı ile yürüttükleri çalışmada, yörede en fazla gıda olarak tüketilen yabancı ot türlerinin; Eremurus spectabilis Bieb., Salvia sclarea L.,Gundelia tournefortii L., Amaranthus retroflexus L., Urtica dioica L., Urtica urens L., Silene vulgaris (Moench) Garcke., Capsella bursa-pastoris (L.) Medik., Rumex crispus L., Mentha aguatica L., Portulaca oleracea L. olduğunu bildirmişlerdir.

Alpaslan (2004), ülkemizde doğada kendiliğinden yetişen otsu bitkilerin sebze olarak tüketiminin her dönem yaygın olduğunu bildirmektedir. Van yöresinde sirmo, mendi ve siyabo, çakır dikeni, kuzukulağı, gıcırtkan, kuş pepesi, karabaldır, 1sırgan otu, çireş otu, yarpuz, boğa dikeni, evelik, inekanl1, ebemgümeçi, kazayağı gibi yöresel isimleri olan bu bitki türlerinin doğal olarak yetişmekte ve yöre halkı tarafindan bu otların toplanıp, yemek, çeşni ve gıda olarak kullandıklarını aynı zamanda bir çok hastalığa karşı da kullanılmakta olduğunu belirtmişlerdir. $\mathrm{Bu}$ bitkilerden bazılarının (sirmo, siyabo, mendi, heliz, dağ kekiği) otlu peynir yapımında kullanıldığı bildirilmiştir.

Satil ve ark. (2007), Madra Dağı ve çevresinde yapılan etnobotanik özellikleri araştırılarak, bölgede gıda amaçlı kullanılan bitkilerin yöresel isimlerini de belirlemişlerdir. Kullanılan bitkilerin pişirilerek tüketildiği gibi çiğ olarakta tüketildiğini bildirmişlerdir. $\mathrm{Bu}$ bitkilerden bazılarının; Oenanthe pimpinelloide
L. (alan maydanozu), Foeniculum vulgare Mill. (arapsaç1), Eryngium campestre L. (boğadikeni), Anethum graveolens L. (dereotu), Daucus carota L. (havuç), Sium sisarum L. var. lancifolium (Bieb.) Thell. (kazayağı), Petroselinum crispum (Mill.) Nyman ex. A.W.Hill (maydanoz), Cynara scolymus L. (enginar), Sonchus asper (L.) Hill subsp. glaucescens (Jord.) Ball. (elek helvasi), Lactuca sativa L. (marul) Taraxacum sp. (tatlihindiba), Cichorium intybus L. (acihindiba), Armoracia rusticana Gaertn. B. Mey. \& Scherb. (eşekturpu) Nasturtium officinale R.BR. (gerdirme), Brassica oleraceae L. (lahana), Eruca sativa Mill. (Roka), Lepidium sativum L. (tereotu), Raphanus raphanistrum L. (turpotu), Stellaria media (L.) Vill. (cicibücü), Asparagus acutifolius L. (tatlı filizotu), Malva neglecta Wallr. (develik), Papaver rhoeas L. (gelincik), Rumex acetosella L. (kuzukulağı), Rumex patientia L. (labada), Urtica dioica L. (1sırganotu) olduğu tespit edilmiştir.

Yeşil (2007), Malatya'nın Akçadağ ilçesine bağlı Kürecik bucağında yaptığı etnobotanik çalışmada; geleneksel olarak kullanılan bitkileri saptamak amacıyla bitkilerin yöresel adları, kullanılışları, kullanılan kısımları, hazırlanışları, uygulanış şekilleri, dozları ve uygulama süreleri hakkında bilgiler derlenmiştir. $\mathrm{Bu}$ çalışmanın sonucunda farklı kullanılışlara sahip 129 takson (123 doğal, 6 kültür) tespit edilmiştir. Bunlardan $45^{\prime} \mathrm{i}$ bitkisel tedavi, 60'1 gıda, 13'ü baharat veya çay, 24'ü hayvan yemi, 16's1 boya, 16's1 yakacak olarak, 28'inin ise bunların dışında farklı kullanılışları olduğu saptanmıştır.

Altundağ ve Özhatay (2009), Iğdır ilinin merkezi Tuzluca, Aralık ve Karakoyunlu İlçelerine bağlı 52 köyünde yaptıkları tarama çalışmalarında 250 bitki örneği toplanmış, bilimsel tayini tamamlanan 110 bitki taksonundan 54 adedi gida, 30 adedi tıbbi, 21 adedi hayvan yemi, 9 adedi ise değişik amaçla kullanılmakta olduğunu bildirmişlerdir.

Göğtepe ve ark. (2008), Kars'ın ilçelerine ait 8 köyde doğal olarak yetişen, gida ve ilaç olarak kullanılan yabani bitkilerin tespit etmek amacı ile yaptıkları çalışmada; 20 familyada 50 bitki türü tespit etmişlerdir. $\mathrm{Bu}$ örneklerin Latince isimleri, familyaları, yöresel adları ve yörede kullanım şekillerini belirlemişlerdir. Gıda olarak; Trogopogon porrifolius (mırcalık), Lathyrus tuberosus (kuş 
konmaz), Rumex sp. (dırşo), Apia malabia (kelemenkeşir), Trogopogon aureus (yemlik), Ferula orientalis (çakşır), Arthemisia absinthium (süpürge otu), Plantago major (belhevis), Capsella bursa (ac1g1c1), Rumex potientia (evelik), Urtica dioica (1sirgan), Alliaria petiolata (dida), Heracleum pastinacifolium, (kabalak, devetaban1), Bellevolia sarmatica (kır çiçeği), Eryngium bilardieri (su dikeni ), Chenopodium sp.(kazayağı), Vicia canescens (küllür), Salvia ceratopylla (öküz pöçüğü), Allium sp.(sirmo) gibi bitki türlerinin kullanıldığını bildirmişlerdir.

Akan ve ark. (2008), Arat Dag1 ve çevresinin (Birecik-Sanlıurfa) etnobotanik özelliklerini tespit etmek amacıyla yaptıkları çalışmada; 49 familya ve 193 cinse ait 299 taksonun 170'sinın etnobotanik özelliginin oldugu tespit edilmistir. Bunlardan 59'u yem, 33'ü yiyecek, 19'u yakacak, 17'si tıbbi amaçlı, 13'ü zararlı, 8'i süpürge yapımında, 5'i süs bitkisi, 5'i boya, 3'ü oyun amaçlı (çocuklar için) ve 11 'i de diger amaçlarla kullanılmaktadır. Yöre halkı tarafindan 33 bitkiye sadece isim verilmis olup, bu bitkilerin herhangi bir kullanımı bulunmadığ tespit edilmiştir. $\mathrm{Bu}$ alanda yöre insanı tarafından gıda olarak kullanılan Eryngium creticum Lam. (çistok), Carduus nutans L. subsp. leiophyllus (Petr.) (kerbes), Centaurea hyalolepis Boiss. (kulindor), Centaurea iberica Trev. ex Spreng Stoj. et Stef. (çakırdikeni), Gundelia tournefortii L. var. armata Freyn et Sint. (kereng), Tragopogon buphthalmoides (DC.) Boiss. var. buphthalmoides (agu), Tragopogon pusillus Bieb. (çarik, porim), Onosma molle DC. (divankosk), Capsella bursa-pastoris (L.) medik (çiçeğe gevr), Sinapis alba L., Sinapis arvensis L. (herdal), Capparis ovata Desf. var. palaestina Zoh., Capparis spinosa L. var. spinosa (keber), Argyrolobium crotalarioides Jaub. et Spach (collik), Lathyrus cicera L. (colba), Vicia narbonensis L. var. narbonensis (collikey keray), Geranium tuberosum L. subsp. tuberosum, Geranium tuberosum L. subsp. desertisyriacum Davis (helikok), Crocus cancellatus Herbert subsp. damacenus (herbert) Mathew, Crocus pallasii Goldb. subsp. pallasi (pivok), Salvia russelii Bentham (künceyi beji), Salvia viridis L. (çobandöşegi), Malva neglecta Wallr., Malvella sherardiana (L.) Jaub. et Spach (kömeç), Urtica dioica L. (1sırgan otu) olduğunu bildirmişlerdir.
Aksakal ve Yusuf (2008), Erzurum ili civarından yaptıkları çalışmada; 20 familyaya ait 72 tür belirlenmiştir. Gıda amaçlı kullanılan türlerin en çok Lamiaceae, Rosaceae, Apiaceae ve Asteraceae familyalarına ait olduğunu, bu türlerin 1 tanesinin toprak üstü kısımları, 14 tanesinin gövdesi, 18 tanesinin yaprakları, 18 tanesinin meyveleri, 1 tanesinin rizomlar1, 1 tanesinin toprak alt1 kısımları, 4 tanesinin tohumları, 3 tanesinin genç sürgünleri, 1 tanesinin tuberleri, 4 tanesinin soğanı kullanıldığı tespit edilmiştir. Tragopogon aureus Boiss., Sambucus ebelus L. gibi bazı türlerin çiğ olarak tüketildiği, 1sırgan gibi bazı bitkilerin ise hem çiğ hemde pişirilerek tüketildiği belirlenmiştir. Antriscus nemerosa, Berberis crataegina ve Berberis vulgaris gibi bitkilerin ise sirke ve limon ile karıştırılarak salatalar hazırlandığı belirlenmiştir.

Yapıcı ve ark. (2009), Kurtalan (Siirt) ilçesinden tespit edilen bazı bitkilerin, etnobotanik özellikleri ve yerel isimleri araştırılmıştır. Çalışma sonucunda 34 taksonun yerel isimleri, tıbbî ve gıda amaçlı kullanımları ile diğer etnobotanik özelliklerini belirlemişlerdir. Toplama sırasında yöre halkıyla ve aktarlarla yapılan söyleşiler sonucu elde edilen bilgiler değerlendirilmiş, bitkilerin latince isimleri ile birlikte, familyası, mahalli adı, toplayıcı ad ve numarası verilmiș, daha sonra bitkinin, biliniyorsa kullanılan kısımları, çeşitli kullanım alanları tespit edilmiştir. Gıda olarak kullanılan bazı bitkiler ve bunlara verilen yöresel isimleri, Alcea striata (DC.) Alef. (hiro), Alliaria petiolata (Bieb) Cavara \& Grande (sarımsak otu), Anchusa azurea Miller (sığır dili, gruz), Aristolochia bottae Jaub. \& Spach (goye deve), Bongardia chrysogonum (L.) Spach (çatlak otu), Cephalaria procera Fisch \& Lall, (gevrek), Cichorium pumilium Jacq (hindiba), Gundelia tournefortii L. (kenger), Hypericum retusum Aucher, (koyun kıran, binbirdelik otu), Malva neglecta Wallr. (ebegümeci, tolik), Ornithogalum narbonense L., (ak baldır), Plantago lanceolata L. (sinir otu), Salvia multicaulis Vahl. (adaçay1), Sinapis arvensis L. (hardal), Teucrium polium L, (meyremhort), Tragopogon longirostris Bisch ex. Schultz Bip. (yemlik) olarak tespit etmişlerdir.

Koca ve ark. (2011), Samsun ve çevresinde yaptıkları çalışmada, yetişen yabani bitkiler, özellikle ilkbahar aylarında kırsal kesimde yaşayan insanlar tarafindan toplanarak pazara getirildiğini, 
son yıllarda doğal ve organik gıdalara karşı tüketicinin artan talebi bu bitkilere ilgiyi artırdığını, bu bitkilerin bir kısmı çiğ veya pişirilerek taze tüketildiği gibi, bir k1smı dondurularak, kurutularak, salamura veya konserveye işlenerek de tüketildiğini bildirmişlerdir. Çalışmada Samsun ve çevresinde gıda amaçlı bitkilerin yöresel isimleri ve kullanım şekillerini tespit etmişler bu bitkilerden, Aegopodium podagraria L. (mendek), Amaranthus retroflexus L. (horoz ibiği), Arum euxinum R.B. Mill. (nünük), Bellis perenis (papatya), Capsella bursa-pastoris (L.) Medik (çoban çantası), Chenopodium album L. (sirken), Coronopus squamatus (yolagelen) Falcaria vulgaris Bernh. (kazayağı), Malva neglecta Wall. (ebegümeci), Mentha aquatica L. (su nanesi), Nasturdium officinale (su teresi), Ornithogalum sp. (çiğdem), Papaver rhoeas (gelincik), Polygonum cognatum Meissn. (madımak), Portulaca oleracea L. (semizotu), Rumex crispus L. (yazı pancar1), Rumex patientia L. (efelik), Silene vulgaris var. vulgaris (şakşak), Smilax excelsa L. (kırçan), Trachystemon orientalis L. (kaldırayak) ve Urtica dioica L. (1sırgan) türlerinin yoğun olarak tüketildiğini tespit etmişlerdir.

Tekin (2011), Erzincan'a bağlı Üzümlü ilçesi ve köylerinde; Üzümlü halkının kullandığı doğal bitkileri ve yöresel isimlerini belirlemek amacı ile yaptıkları, çalışmada, 44 familyaya ait 140 tür belirlemişlerdir. Bunların 60 tanesinin gıda amaçlı kullanıldığı tespit edilmiştir. Gıda olarak yöre halkı tarafindan kullanılan bitkilerin bazılarının; Amaranthus retroflexus L. (kırmız1 pancar), Bilimsel, Astrodaucus orientalis (L.) Drude, Echinophora sp. (çordik), Falcaria falcarioides (Bornm. \& Wolff) Wolff (kazayağı), Turgenia latifolia (L.) Hoffm. (pitrak), Cichorium intybus L. (sakızotu), Echinops orientalis Trautv. (topuzdikeni), Gundelia tournefortii L. var. tournefortii (kenger), Tragopogon dubius Scop. (yemlik), Berberis vulgaris L. (karamuk), Anchusa arvensis (L.) Bieb. subsp. orientalis (L.) Nordh., Anchusa leptophylla Roemer \& Schulte, (sığırdili), Cerinthe minor L. subsp. auriculata (Ten.) (hışhış), Capsella bursapastoris (L.) Medik (çobançantası), Viburnum opulus L. (girabolu), Silene vulgaris (Moench) Garcker var. vulgaris (gelinparmağı), Chenopodium album L. subsp. album (tel pancarı), Salvia sclarea L. (adaçay1), Ziziphora clinopodioides Lam. (kekik), Asphodelus aestivus L. (çiriş), Malva neglecta Wallr. (ebegümeci), Glaucium sp. (gelincik), Papaver rhoeas L. (gelincik), Plantago major L.(bağa yaprağı), Polygonum cognatum Meisn. (madımak), Rheum ribes L.(1şgın), Rumex acetosella L. (kuzukulağı), Rumex crispus L. (evelik), Portulaca oleracea L. (pirpirim otu) olduğunu bildirmişlerdir.

Güneş ve Özhatay (2011), Kars ve çevresindeki köylerde yabani bittkilerin halk arasındaki kullanımlarını saptamak amaciyla yaptıkları çalışmada 32 familyaya ait kullanımı olan toplam 95 takson kaydedilmiştir. Çalışmaları sonucunda, bitkilerin kullanımları, ilaç, gıda ve diğer kullanımlar olmak üzere 3 kategoride toplanmıştır. Bitkilerin bilimsel adları, yöresel adları, familyaları, kullanılan kısımları ve kullanım şekillerini bildirmişlerdir. Gıda olarak kullanılan bitkilerin; Trogopogon porrifolius (mircalık), Lathyrus tuberosus (kuşkonmaz), Rumex sp. (dırşo), Apia malabi (kelemenkeşir), Trogopogon aureus (yemlik), Ferula orientalis (çakşır), Arthemisia absinthium (süpürge otu), Plantago majör (belhevis), Capsella bursa (acigic1), Rumex patientia (evelik), Urtica dioica (1sirgan), Alliaria petiolata (dida), Heracleum pastinacifolium (kabalak, devetaban1), Bellevolia sarmatica (kır çiçeği), Eryngium bilardieri (su dikeni), Chenopodium sp. (kazayağı), Vicia canescen (küllür) Salvia ceratopylla (öküz pöçüğü), Rosa canina (kuşburnu), Allium sp. (Sirmo) olduğu tespit edilmiştir.

Akgünlü (2012), Kilis ve Antep illerinde sebze olarak kullanılan bazı yabani bitki türlerini kullanım şekillerini ve yöresel adlarını tespit etmiş ayrıca bu bitkilerin nineral madde kondantrasyonlarını incelemiş, çalışma sonucunda illerde sebze olarak tüketilen, Arum dioscorides (gavurpancarı), Chenopodium album (kazayağı), Malva sylvestris (ebegümeci), Mentha longifolia (yarpuz), Nasturtium officinale (su teresi), Papaver rhoeas (gelineli), Polygonum aviculare (kuş ekmeği), Rumex acetosella (kuzukulağı), Sinapis alba (hardal) ve Urtica dioica (1sırgan otu) gibi bitkilerin olduğunu bildirmiştir.

Korkmaz ve Alpaslan (2014), Erzincan ili sınırları içerisinde yer alan Ergan Dağ köylerde yaşayan yöre halkı tarafindan kullanılan bitkilerin etnobotanik özelliklerinin belirlenmesi 
amacıyla 2011 yılında yaptıkları bir çalışmada; araştırma alanındaki 41 familyaya ait toplam 122 taksonun, 82'si gida, 56's1 tıbbi, 22'si yem, 4'ü eşya, 3'ü süs, 2'si balık ağı ve 6's1 yakacak amacıyla kullanıldığını belirtmișlerdir. Çalıșmanın sonucunda gida olarak kullanılan bitki türlerinin bazılarının, Chenepodium album (telotu), Chenepodium foliosum (yabaniçilek), Allium sintenisii (dağsarmısağı), Eryngium billardieri (eşekdikeni), Prangos ferulacea (çaşur), Prangos pabularia (holoz), Muscari coeleste (zağik), Eremurus spectabilis (çiriş), Centaurea depresa (peygamberdüğmesi), Circium arvense (köygöçüren) olduğunu bildirmişlerdir.

Kaval ve ark. (2014), Doğu Anadolu Bölgesi'nde Geçitli (Hakkari) ilçesinde şifalı bitkiler tespiti üzerine yaptıkları çalıșmada yöre halk tarafından tıbbi amaçlar için toplanan yabani bitkileri tanımlamak, ne amaçla kullandıklarını ve yerel isimlerini belirlemek amacı ile yaptıkları etnobotanik çalışmasında; 70 bitki taksonu ve bir mantar toplamış, kullanılan parça ve hazırlama yöntemleri ve yöresel isimlerini incelenmiş ve kaydedilmiştir. Bitkilere ait en yaygın türlerin, Asteraceae, Apiaceae, Lamiaceae, Rosaceae, Euphorbiacae, Fabaceae ve Malvaceae familyalarına ait olduğunu tespit etmişlerdir. Yörede bulunan insanların bu bitkileri yoğun bir şekilde kullandığını, Geçitli'de yetişen yabani bitkilerle ilgili önceki laboratuvar çalışmaları ve bu çalışmadan elde edilen veriler, büyük ölçüde etnobotanik kullanımlarının kanıtlandığ 1 ve Geçitli'de yetişen tedavi amaçlı bitkilerin benzer hastalıkların tedavisi için dünyanın farklı yerlerinde de kullanıldığını bildirmişlerdir.

Korkmaz ve Karakurt (2015), Kelkit (Gümüşhane) yöresinde yaşayan halkın gida olarak kullandığı doğal bitkileri belirlemek amaciyla yaptıkları çalışmanın sonucunda; toplam 30 familyaya ait 85 taksonun gida olarak kullanıldığını tespit etmişlerdir. Takson sayıları bakımından ilk beş sırada yer alan familyaların sirasıly Rosaceae, Asteraceae, Apiaceae, Lamiaceae, Chenopodiaceae olduğunu belirtmişlerdir. Yörede bitkilerin en çok kullanılan kısımlarının sırasıyla yaprak, meyve ve çiçek olduğunu, bu bitkilerin çoğunlukla çiğ olarak yenilmekte veya yemeği yapılarak tüketilmekte olduğunu belirtmişlerdir. Anethum graveolens (dereotu), Daucus sp. (gımı), Daucus carota (havuç), Eryngium billardieri (çakır dikeni, boğa dikeni), Falcaria falcarioides (kazayağı), Petroselinum crispum (maydanoz), Pimpinella corymbosa (ezerteli, yaban kerevizi), Prangos pabularia (çakşır), Arctium minus (boz diken), Centaurea depressa (peygamber düğmesi), Cichorium intybus (sütlü ot, çitlankuş), Cirsium arvense (boz diken), Echinops orientalis (şeker dikeni), Helianthus tuberosus (yer elmasi), Scorzonera tomentosa (yersakızi), Tragopogon buphthalmoides var. buphthalmoides (yemlik, dede sakal1), Tragopogon dubius (yemlik, dede sakal1), Berberis vulgaris (kızamık, kızambuk), Asperugo procumbens (lemislik), Brassica elongata (eşek turpu), Capsella bursa-pastoris (çoban çantas1, serçegözü), Stellaria media subsp. media (koyun gözü), Silene sp. (gelin parmağ), Chenopodium sp. (liviç), Chenopodium sp. (hoşveren), Chenopodium album subsp. album (yaban tel pancar1), Sedum album (beyaz dam koruğu), Sedum sempervivoides (al dam koruğu), Coronilla orientalis var. orientalis (maya otu), Geranium tuberosum (kahmut), Mentha sp. (nane), Mentha longifolia (yarpuz, dağ nanesi), Micromeria cristata subsp. orientalis (kekik), Thymus sipyleus subsp. sipyleus (kekik), Origanum vulgare (anuk), Antricus sp. (çayır çimleği) Papaver dubium (gılla, haşhaş), Glaucium grandiflorum var. grandiflorum (yabani haşhaş, deli gilla), Papaver rhoeas (Gelincik, haşhaş), Rumex acetosella (kuzu kulağı), Rumex tuberosus subsp. horozontalis (kuzu kulağı), Polygonum cognatum (madımak, madımalak), Rumex crispus (evelik), Portulaca oleracea (semiz otu), Consolida orientalis (ekin otu), Alchemilla sp. (devetaban1, aslanpençesi), Alchemilla minusculiflora (devetabanı, aslanpençesi), Urtica dioica (1sırgan) gibi bitki türlerinin yoğun olarak tüketildiği tespit edilmiştir.

Kadıoğlu ve ark. (2015), Kop'un Aşkale ve Bayburt sınırları içerisinde yer alan halk tarafindan bilinen ve değerlendirilen bitkileri belirlemek için yaptıkları çalışmalarda; hedeflenen 14 köyde yaşayan tecrübeli ve bilgili kişilerden yöresel bitkilere ait bilgilerin alındığını belirtmişlerdir. Çalışma alanında halen kullanılan bitkiler; familyaları, latince ve yöresel isimleri, kullanılan kısımları ve kullanım şekilleri ile birlikte belirlenmiştir. Çalışmalar sonucu halk tarafindan değişik şekillerde (gıda, tıbbi, süs, yem, eşya vb.) kullanılan 44 familyaya ait 200 bitki türünün tespit edildiğini bildirmişlerdir. 59 bitki türünün gida 
olarak tüketildiği bildirmişlerdir. Bu bitkilerin bazılarının; Anthriscus nemorosa (piçekli, frenk maydanozu), Asparagus persicus L. (meluci, meloci), Atriplex sp. Atriplex prostrata (k1z1lca, eşgi, eşki), Eremurus spectabilis (çiriş), Beta lomatogana (kızılca), Beta trigyna (evelik/yabani paz1), Berberis vulgasris, Berberis integerrima (kızamı/ karambuk/kızambuk), Caltha polypetala (atayağ1, lulipar) Capsella bursa-pastoris L. (kuşgözü), Centaurea iberica (çakır dikeni), Cephalaria syriaca (L.) (orum), Chaerophylum sativum L., Chaerophylum ancelicifolium L. (gimi, kımi, cac1k), Chenepodium Iranicum (yabani, 1spanak/ tel pancarı/kül pancarı), Cerinthe minör (hışhış), Cirsium rhizocephalum (madak, mandak, geçimemesi), Cotonoester sp. (koyun gözü), Crataegus orientalis (aloş/aloç), Cerasu sangustifolia (yabani kiraz), Echinops pungens (topuz dikeni), Elaeagnus angustifolius (yabani iğde), Eremurus spectabilis (çiriş), Eryngium billardieri (boğa dikeni, kenger), Falcaria vulgaris (kazayağ1, gazayaği), Ferula orientalis, Prangos ferulaceae L. (çaşır, çaşur), Geranium tuberosum (kahmut, çahmut, adol), Gladiolus kotschyanus (karga soğan1), Gundelia tournefortii (kenger, kengel), Helianthus tuberosus (yer elması, yıldız kökü), Heracleum persicum, Heracleum pastinacifolium (gımi, hırhındilik), Hippophae rhamnoides L. (Sincan), Juniperus communis L.(çeçem/kekem gagası), Arctium minus (Hill) (kalağan, şapılot, devedabani), Lamium amplexicaule L. (emzik), Lathyrus tuberosus L. (koşgoz, goçgoz, kozkoz, goşgoz), Malabaila dasyantha (kelemenkeşir, kelemen keşişi), Malva neglecta (ebem kömeci/gagala ot/,ebem kemesi), Malus sylvestris (yabani elma, eşki alma), Muscari parviflorum, Muscari neglectum (camış memesi), Nepeta racemosa, Nepeta betonicifolia (pisik nanesi), Onosma isauricum (emzik otu), Onopordium acanthium (kavlugan), Opapanax hispidus (keküre, kekire), Ornithogalum narbonense L. (kurtkirişi, gurtsoğanni), Orchis palustris (çiğdem), Papaver arenarium, Papaver macrostomum (haşhaş), Polygonum cognatum /Polygonum aviculare (kuşekmeği, ebemekmeği, madımalak, madımak), Polygonum amphium L. (kuzu kulağı), Plantago majör (bağa yarpağı), Pyrus syriaca (yabani armut) gibi türler olduğu bildirilmiştir.

Kadığlu ve ark. (2016), Erzurum ve Erzincan ilerinde 2011-2013 yıllarında sebze olarak tüketilen yabani bitki türlerini tespit etmek amacı ile yaptıkları çalışmalarda, 37 familyada 182 bitki türü tespit edilmiş, bu bitkilerin yöresel adları, bitkinin kullanılan kısımları, kullanım şekilleri öğrenilerek kayıt altına alınmıștır. Bu bitkilerin, kök, gövde, sürgün, çiçek, dal, yaprak, tohum ve yumru gibi kısımlarının sebze olarak tüketildiği, bitkinin yenilen kısımlarının yöreden yöreye farkl1lık gösterdiği tespit edilmiştir. Tespit edilen bitki türlerinin yöre halkı tarafindan taze olarak tüketildiği gibi, kurutarak, salamura edilerek, turşuya işlenerek, dondurularak veya konserve şeklinde muhafaza edilerek uzun süre tüketildiği, genellikle, çiğ (salata), yemek, sarma, çorba, börek içi, turşu, reçel olarak değerlendirdikleri bildirilmiştir. Gıda olarak kullanılan bu bitkilerin bazılarının aynı zamanda, baharat olarak, tat ve koku vermek için, çay olarak ve tedavi amacı ile de kullanıldığ1 tespit edilmiştir. Yoğun olarak kullanılan bitkilerin bazılarının; Rumex obtusifolius L. subsp. subalpinus (abaza, alabaz, gemdaş1, lapaza, çayır pancarı, çayır eveliği), Asperugo procumbens L. (akbuncuk) Origanum acutidens (annuk), Cardamine uliginosa (acigic1), Ornithogalum narbonense (ak pancar), Stellaria media (civelek, civciv otu, serçegözü, bibercik, karga bağırsağı), Prangos ferulacea (çaşır, çagşur, heliz), Echinophora tenuifolia L.subsp. sibthorpiana (çordik), Capsella bursa-pastoris (çobançantası kuşgözü, kuşekmeği, kuşkuş otu, bulgurcuk, lahanica), Allium tuncelianum (tunceli sarımsağ1, sirim), Onopordum acanthium (gavlugan, gangol, kalkan, gelenk), Rumex crispus (evelik, turşu, öküzekşi), Rumex acetosella, Rumex scutatus (kuzu kulağ 1 , ekşice, geyik kulağ 1 , tirşo, neri ), Malva neglecta (ebe gümeci, ebemekmeği, ebeköyneği, dallik, silmas), Salvia aethiopis (kazankaras1, dadırgan), Anchusa leptophylla sp. Leptophylla (sığırdili), Papaver dibium, Papaver rhoeas (gelincik, haşhaş), Rumex conglomeratus (kızıl baldır, kızılca), Chaerophyllum bulbosum (kımı, çemlik, mendek, hırhandırık), Gundelia tournefortii L. var. tournefortii (kenger), Arum detruncatum var. detruncatum (gavur pancar1), Geranium tuberosum (kestane otu, kehmut), Polygonum aviculare, Polygonum cognatum (madımak), Chenopodium album L. subsp. album, (istanbul pancarı, tel otu, yabani 1spanak), Urtica dioica (1sırgan, gezgezük), Convolvulus arvensis 
(sarmaşı), Echium italicum (öküzdili), Portulaca oleracea (semizotu, pirpirim ), Plantago majör (sinir otu bağa yaprağı, damarlı ot, havvos otu, pelhevis), Bunias orientalis (psikongalı, eşek turbu, mananık), Tragopogon dubius, Tragopogon longirostris (yemlik, spink, spidak) gibi bitki türleri olduğu bildirilmiştir.

Ece ve ark. (2018), Biga ve köylerinde geleneksel olarak değişik kullanım şekilleri olan bitkilerin yöresel adları bilimsel adlarını belirlemek için yaptıkları çalışma sonucunda, yörede doğal yayılış gösteren ve geleneksel kullanımı olan 142 taksona ait 283 bitki adı tespit edilmiştir. Biga'da bitkilerin geleneksel adlandırılmasında en yaygın kullanılan yaklaşımın benzetmeye dayalı olduğu belirlenmiștir. $\mathrm{Bu}$ bitki türlerini isimleri verilirken, bitkinin özelliğine göre; sütleğen, sütlüce, sütlü ot, renk özelliğine göre; altın çiçeği, altın otu, beyaz kobalak, kara 1sırgan, karabaş, insan adına göre; adamotu, adem otu, çiller, gülfatma, sultan otu, kısa mahmutotu, hayvan adına göre; arı otu, atkuyruğu, balık otu, çakalbağı, organ adına göre; kuşburnu, kuzukulaği, ekşi kulak, tavşanmemesi, katırkuyruğu, nesne adına göre; kırkkilit otu, çıngırak otu, çoban çantası, sabun otu, tespih çalısı, tat özelliğine göre; dibitatlı, ekși kulak, ekși labadik, zehirli olma özelliğine göre verilen adlar; acı baldıran, ağı otu olarak tespit edilmiştir.

$\mathrm{Bu}$ çalışma ile Kars ilinde sebze (gıda) olarak tüketilen yabani bitkileri tespit etmek, tür teşhislerini yapmak, belirlenen bitkilere ait herbaryum ve tohum örneklerini gen bankalarına göndererek muhafazasını sağlamak, yöre insanından bu bitkilerin kullanım şekillerini öğrenerek elde edilen bilgilerin gelecek nesillere aktarmak amaçlanmıştır. Ayrıca, bu çalışmadan elde edilen bulguların taksonomistlere ve botanikçilere kaynak olacağı ve ileride yapılacak çalışmalara (1slah ve kültüre alma çalışmaları)

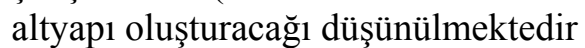

\section{MATERYAL ve METOT}

$\mathrm{Bu}$ çalışma; 2015-2016 yılları arasında Doğu Anadolu Bölgesi'nde yer alan Kars ilinde yürütülmüştür. Kars iline ait her ilçeden (Akyaka, Arpaçay, Digor, Kağızman, Merkez, Sarıkamış, Selim) o bölgeyi temsil edecek şekilde (rakım düşüklüğü ve yüksekliği ve etnik ve kültürel yapısı göz önüne alınarak) en az 8 köyde o yılın muhtelif zamanlarında arazi sürveylerine çıkılmıştır (Engels, 2011; Tan ve ark., 2013). Toplama çalışmalarında öncelikle o yörenin pazarları gezilmiș, yöreyi gezerken ve yörede uzun süre yaşayan kişilerden konuyla ilgili bilgiler alınmıştır. Araştırmada yöre insanına; bulunduğu yerde sebze olarak (g1da) tüketilen bitkilerin neler olduğu, bitkiye verilen yöresel isimler, bitkinin toplanma şekli ve bitkinin hangi kısımlarının toplandığ bitkinin toplanan kısımlarının nasıl kullanıldığ 1 hakkında sorular sorulmuş, bilgi veren kişiler eşliğinde söylenen bitkiler tespit edilerek, elde edilen bilgiler kaydedilmiştir. Bilgi veren kişinin rehberliği sağlanamadığ 1 takdirde, toplanan örnekler kişiye gösterilerek onaylatılmıştır. Teşhislere uygun bitkiler toplanarak, tekniklere uygun herbaryumlar hazırlanmıș bitkilere ait tohum örnekleri alınmışıır (Tan ve Taşkın, 2013). Herbaryum örnekleri ve çekilen fotoğraflar yardımı ile tür teşhisleri, Erzincan Binali Yıldırım Ünüversitesi Fen Fakültesi Biyoloji Bölümünden Prof. Dr. Ali Kandemir tarafından gerçekleştirilmiştir. Tespit edilen bitkilerden alınan örneğin, latince adları, yöresel adları, bitkinin kullanılan kısımları, kullanım şekilleri ve zamanları, diğer kullanım amaçları, bulunduğu yerin adresi, rakımı, koordinatları ve bilgi alınan kişinin adresi öğrenilerek kayıt altına alınmıştır. Kayıt altına alınan bu bilgiler toplama formlarına işlenerek, hazırlanan herbaryum örnekleri ve tohum örnekleri toplama formları ile birlikte Türkiye Tohum Gen Bankasina (Ankara) ve Ulusal Tohum Gen Bankasına (Menemen/ İzmir) gönderilmiştir.

\section{BULGULAR ve TARTIŞMA}

$\mathrm{Bu}$ çalışmada Kars ilinde kullanılagelen doğal bitkilerin çoğunluğunun yenilen-içilen bitkilerden oluşu beslenme ve sağlıkta doğal floradan henüz uzaklaşılmadığ1 gözlemlenmiştir. Halk, ihtiyacınıcivar dağ ve ormanlardan kendisi toplayarak karşıladığ 1 için bu gelenek Kars ili, ilçe ve köylerinde hala sürmektedir. Çalışmalarımız sonucunda yöre insanı gida olarak kullanılan bu bitkilere yaşadıkları kültüre bağlı olarak farklı isimler verdiği belirlenmiştir. Kars ilinde beslenme amacıyla bitki toplamacılığının önemli bir geçmişi vardır. Birçok yabani bitkinin toprak üstü kısmı veya kökleri yöre halkı tarafindan sebze olarak 
kullanılmaktadır. Bunlar çiğ veya pişmiş olarak yenildiği gibi kurutularak, salamura halinde veya turşu şeklinde de tüketilmektedir. Kullanılan yabani bitkilerin çoğunluğu sebze-meyve kategorisinde olup, yemeklik olarak kullanılanların genelde soğan ve bulgur ile karıștırılarak pişirildiği ve üzerine sarımsaklı yoğurt, (çiğg-çig) karıştırılarak birlikte yenildiği, meyvelerinden yararlanılan bitkilerin ise şurup ve reçel gibi değerlendirildiği belirlenmiştir. Çalışmanın yürütüldüğü Kars ilinde gida olarak kullanılan bitkilere ait özellikler Çizelge 1'de verilmiştir.

$\mathrm{Bu}$ çalışmada, Kars ili, ilçe ve köylerinde sebze olarak tüketilen 87 adet yabani bitki türünün yöresel adları, türkçe ve latince adları, familyaları, bitkinin kullanılan kısımları, tüketim şekilleri, toplama yerleri yerler ve kullanma zaman1periyodu tespit edilmiştir. Kars ilinde sebze olarak tespit edilen bitki türlerine ait Türkçe isimler Güner (2012)'e göre kaydedilmiştir (Çizelge 1). Çalişmalarımızda yöre halkının sebze olarak tükettiği bu bitki türlerinin daha çok Asteraceae, Lamiaceae, Apiaceae, Polygonaceae familyasına ait olduğu tespit edilmiştir. Tekin (2011), Erzincan'a bağlı Üzümlü ilçesi ve köylerinde; tespit ettikleri türlerin ait olduğu ilk dört familyanın; Asteraceae, Fabaceae, Rosacea ve Lamiaceae familyası olduğunu belirtmiştir. Korkmaz ve Karakurt (2015), Kelkit (Gümüşhane) yöresinde halkın gida olarak kullandığı doğal bitkileri ilk beş sırada sırasıyla Rosaceae, Asteraceae, Apiaceae, Lamiaceae, Chenopodiaceae familyalarımda yer aldığını bildirmişlerdir. Aksakal ve Yusuf (2008), Erzurum ve Çevresinde gıda amaçlı kullanılan türlerin en çok Lamiaceae, Rosaceae, Apiaceae ve Asteraceae familyalarına ait olduğunu, Kaval ve ark. (2014), Geçitli (Hakkari) ilçesinde şifalı bitkiler tespiti üzerine yaptıkları çalışmada, tespit edilen bitkilere ait en yaygın türlerin, Asteraceae, Apiaceae, Lamiaceae, Rosaceae, Euphorbiacae, Fabaceae ve Malvaceae familyalara ait olduğunu tespit etmişlerdir. Yapılan çalışmalar bizim çalışmalarımızla önem sırası farklı olsada gida olarak kullanılan bitkilere ait familyalar benzerlik göstermektedir.

Öte yandan Kars ilinden elde ettiğimiz sonuçlar ile yurdumuzun çeşitli yerlerinde yapılan araştırmalar karşılaştırıldığında, bitkilerin büyük bir çoğunluğunun halk tarafindan yöresel isimlendirilmesinde benzerlikler görülmüs ancak bazı bitki türlerinin yöresel isimlendirilmesinde ise farklılıklar görülmüştür (Alpaslan, 2004; Akan ve ark., 2008; Yapıcı ve ark., 2009; Güneş ve Özhatay, 2011; Koca ve ark., 2011; Tekin, 2011; Akgünlü, 2012; Korkmaz ve Alpaslan, 2014; Kadıŏlu ve ark., 2015; Korkmaz ve Karakurt, 2015; Kadıoğlu ve ark., 2016; Ece ve ark., 2018). Zira bitki isimlerindeki farklılıkların bitkilerin yetiştiği bölgelerin coğrafi yapısı, bu bölgelerde yaşayan insanların etnik ve kültür farklılıklarından kaynaklandığı düşünülmektedir.

Bulgularımızda gida olarak kullanılan bazı bitki türlerine yöre halk1 tarafından verilen isimlerin; Urtica diaco L. (1sirgan, kevges, gezgezik, cincar, gıcırdikeni), Eremurus spectabilis Bieb. (çiriş, gullik kiriş), Portulaca oleracea L. (pirpirim), Polygonum cognatum Meissn, (madımak, (kuşyemliği, nanacüce, cücenuk), Rhuem ribes L., ı̧̧̧ıı, ribes, Rumex crispus L. (evelik, tirşo), Rumex scutatus L. (turşu, taş turşusu, kuzu kulağı, ekşimen), Plantago majör subsp majör L., Malva neglecta Wall. (ebemkömeci, ebemekmeği, ememgömleği, derden, dollik, gargot), Mentha longifolia (L.) L. (yarpuz, punk, tüylünane), Silene vulgaris (Moench) Garcker var. vulgaris, gelin parmağı, vircır pancarı, koyunkulağı, hatunparmağ1, Capsella bursa-pastoris (L.) (medik, hırındik, acıgıc1), Iravançiçeği, Sinapis arvensis L. (tülpenk, mananık, turpotu), Cardamine uliginosa Bieb. (ac1gıc1, su teresi), Tragopogon sp, yemlik, sipink, Eryngium campestre L. (eşek dikeni, topuzdikeni), Anthriscus sylvestris (L.) Hoffm. (kım1, mendek), Özek, Ferula orientalis L. (kıngor, çakşır, çağşur, heliz), Beta trigyna Walds. Et. Kit. (kırpazıs1, pazı, yabani ıspanak, sılk, çayırpancarı) olduğu tespit edilmiştir.

Araştırma sonuçlarına göre; Kars ilinde yöre halkının Lamiaceae familyasına ait olan bitkileri daha çok baharat, çay ve tıbbi olarak kullandığı, Apiaceae familyasına ait bitki türlerini ise salamura ve turşu yapımında kullanarak tükettikleri tespit edilmiştir. Bölgede bu bitkilerin turşu ve salamura yapıldığ donduruculara konarak uzun süre muhafaza edildiği, böylece bitkilerin taze olarak tüketimlerinin uygun olmadı $\breve{g}_{1}$ zamanlarda bile tüketilmesinin söz konusu olduğu tespit edilmiştir. 


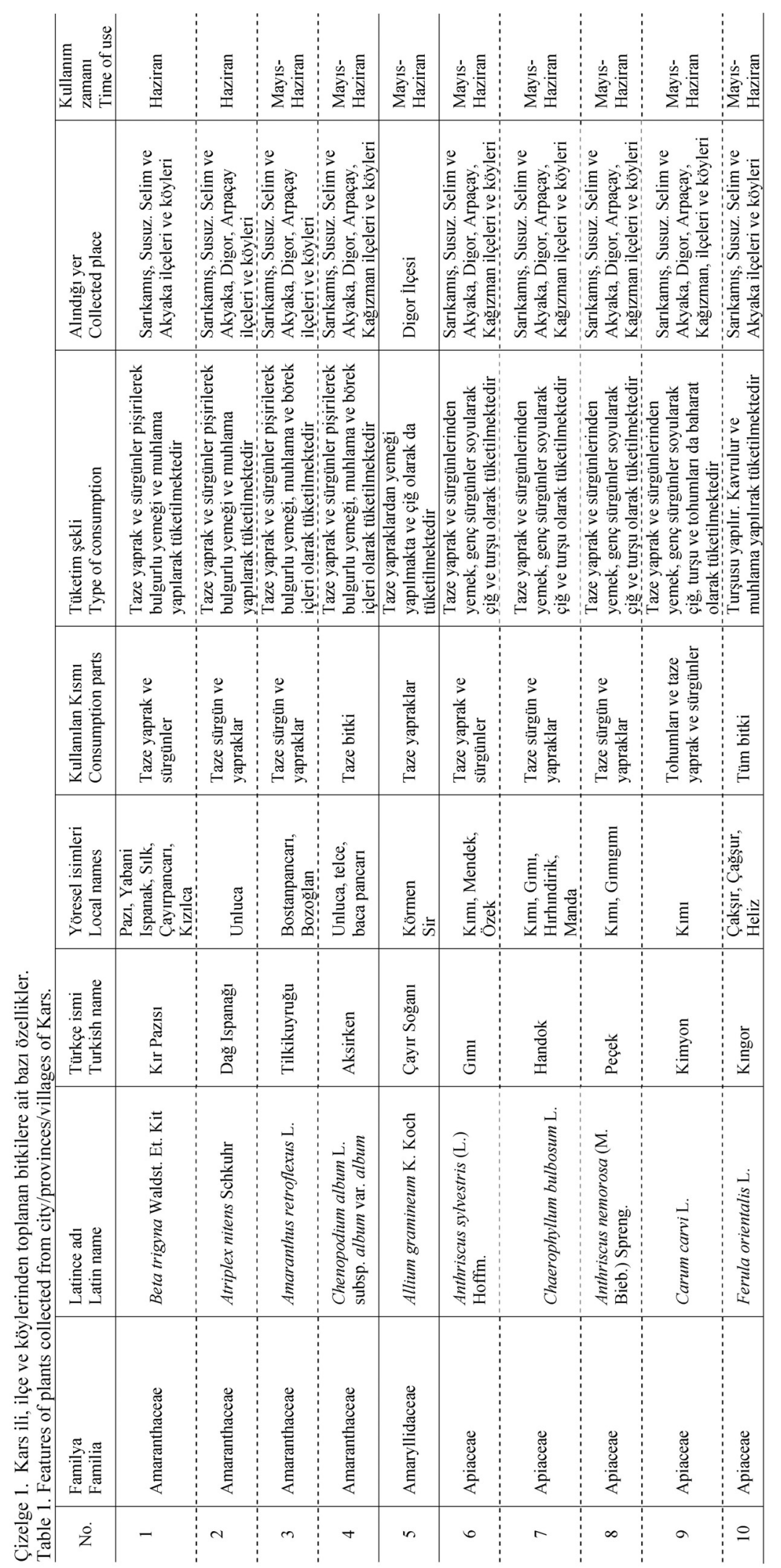




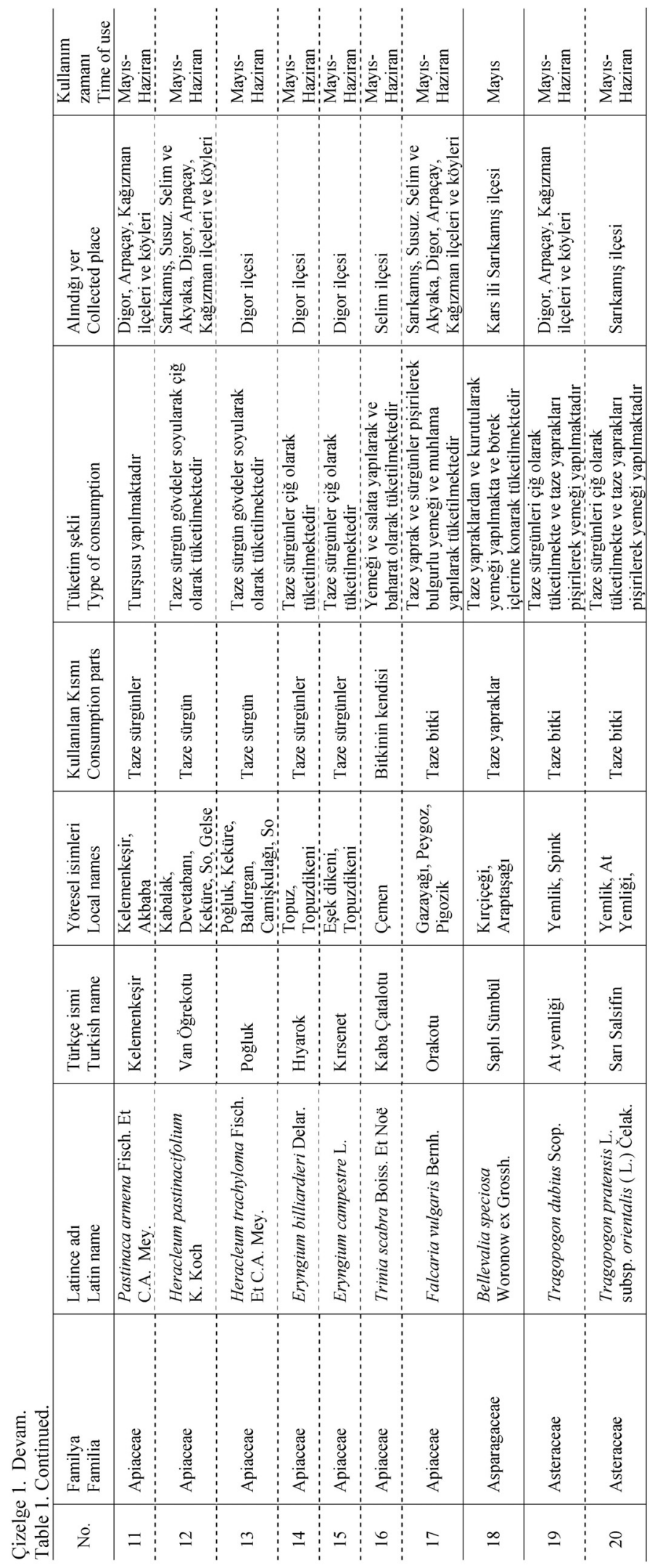




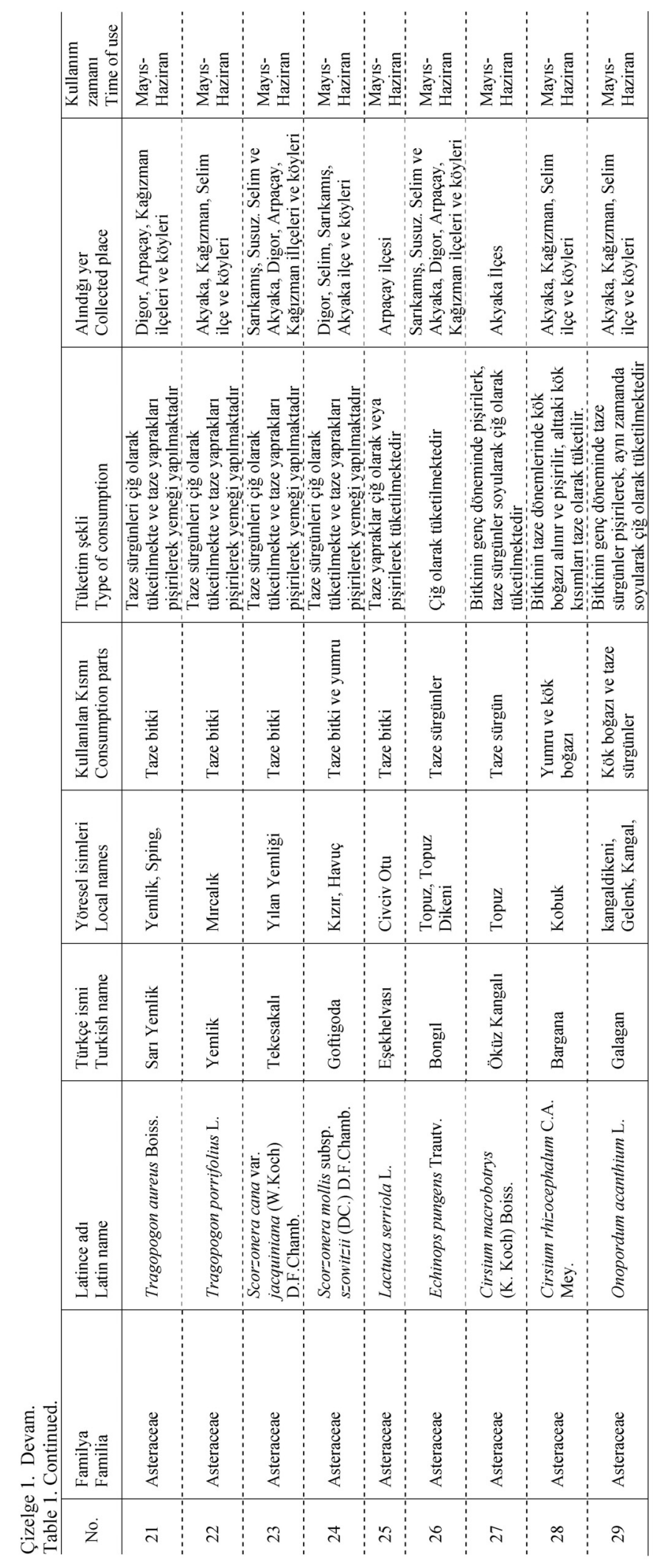




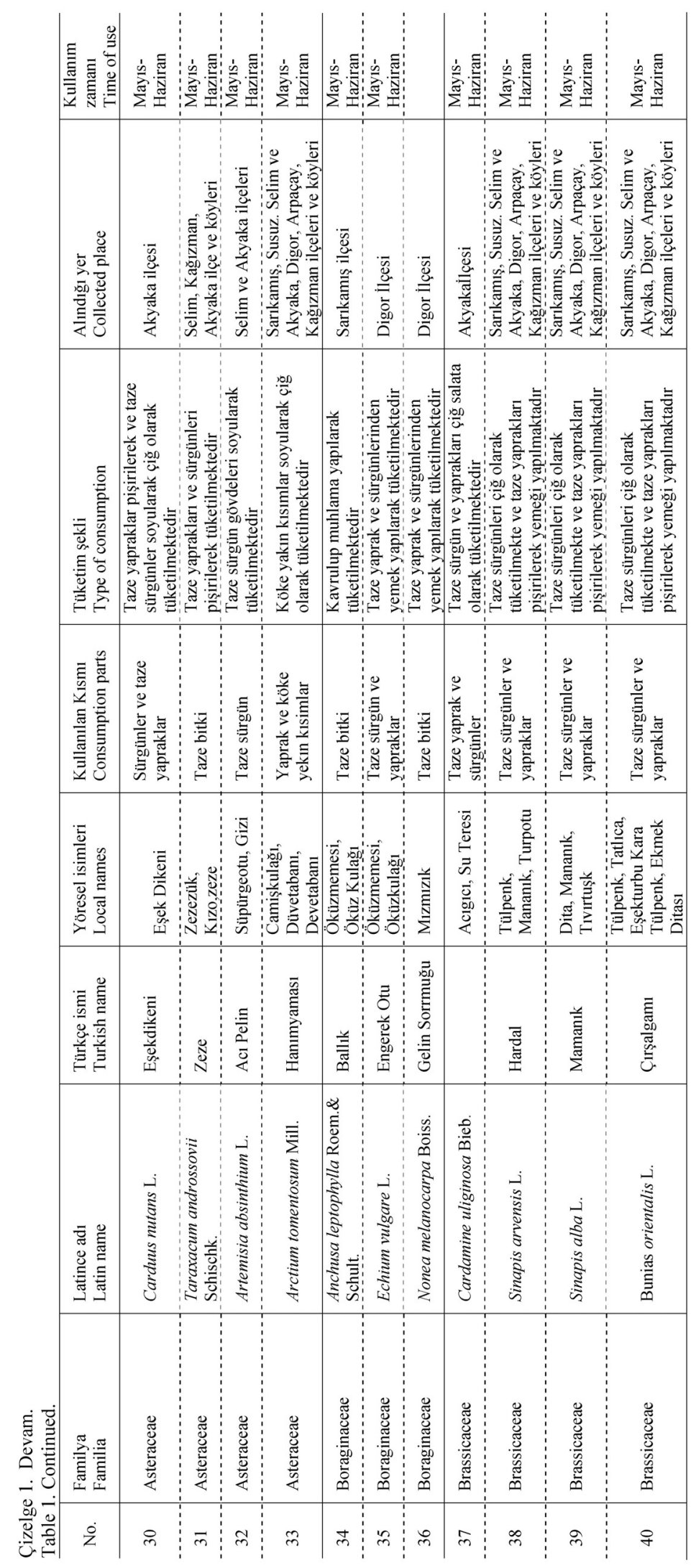




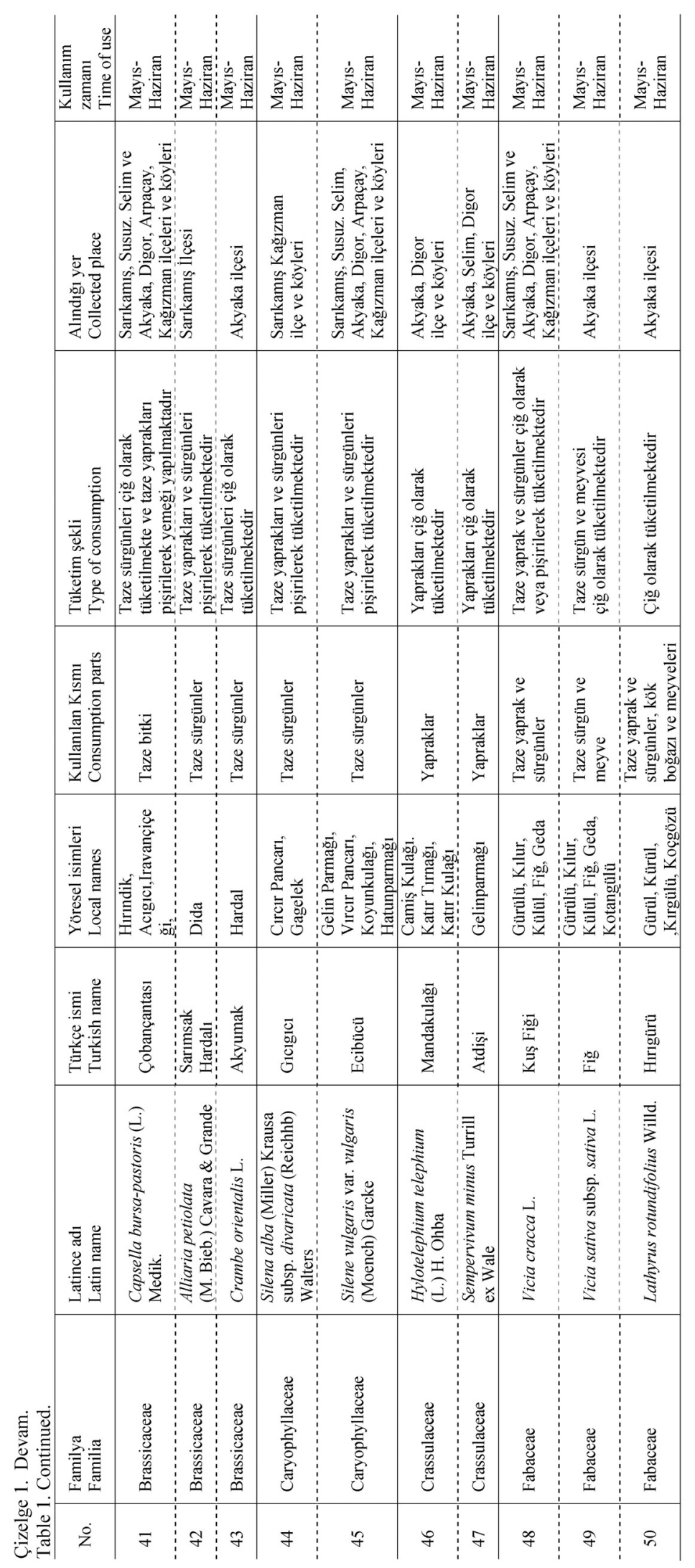




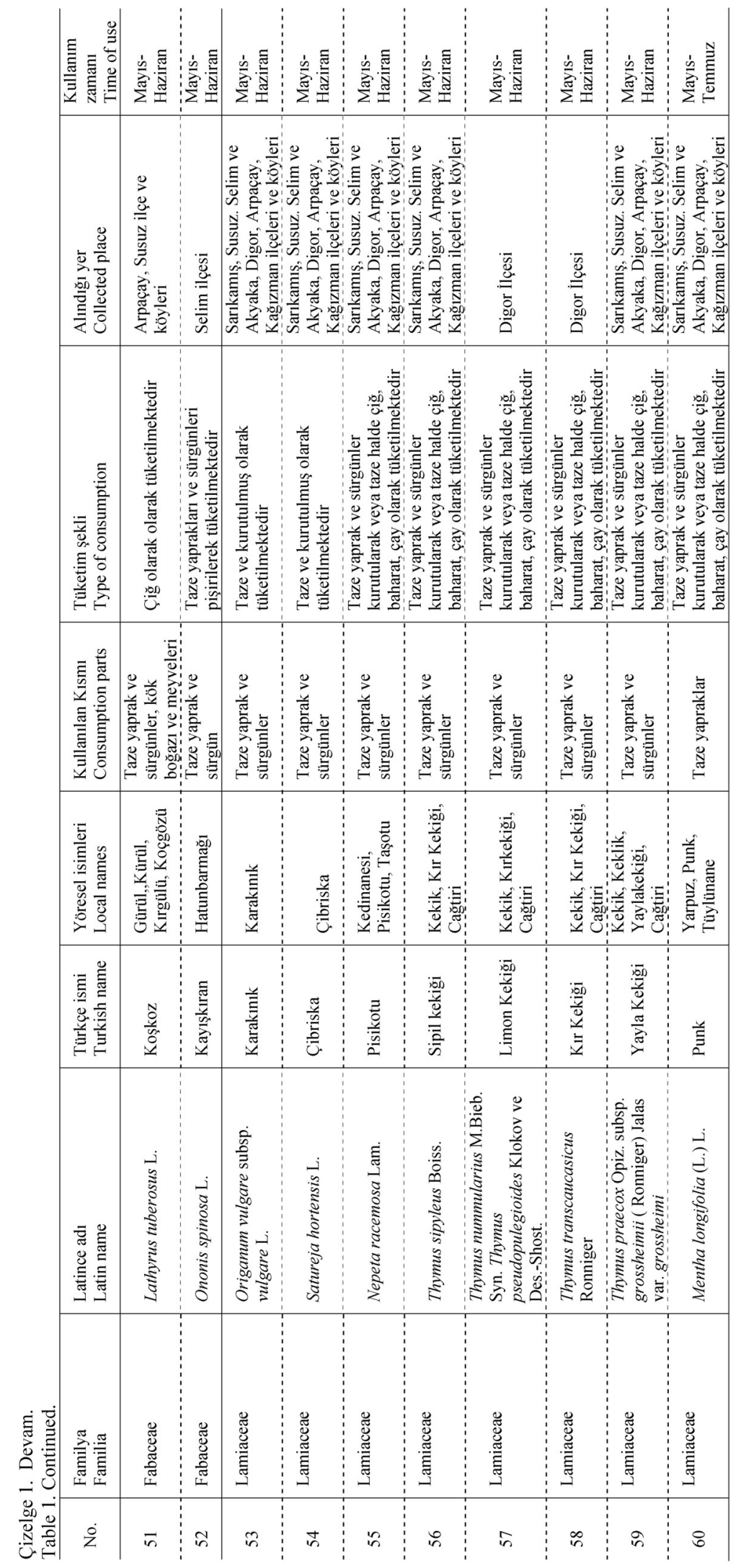




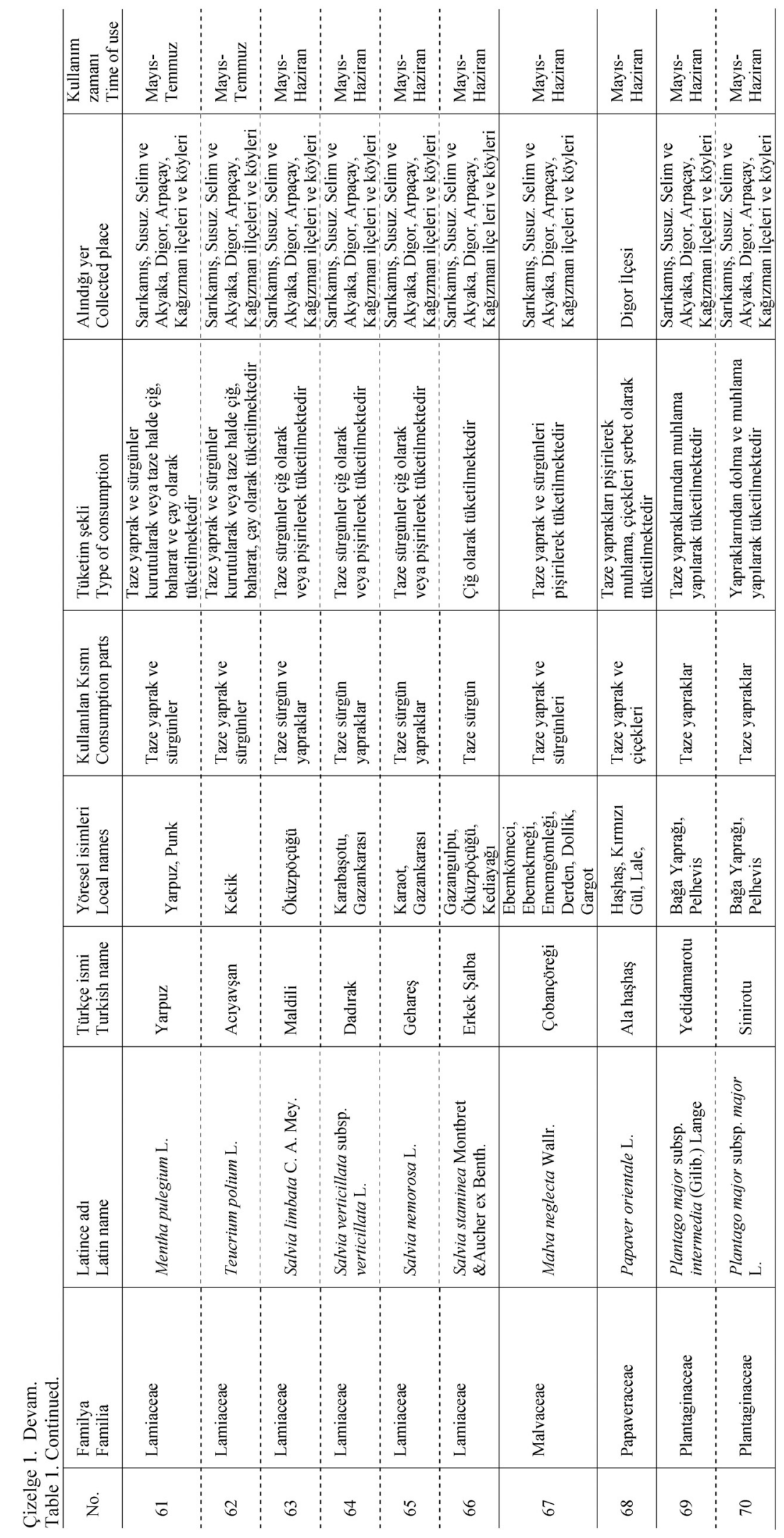




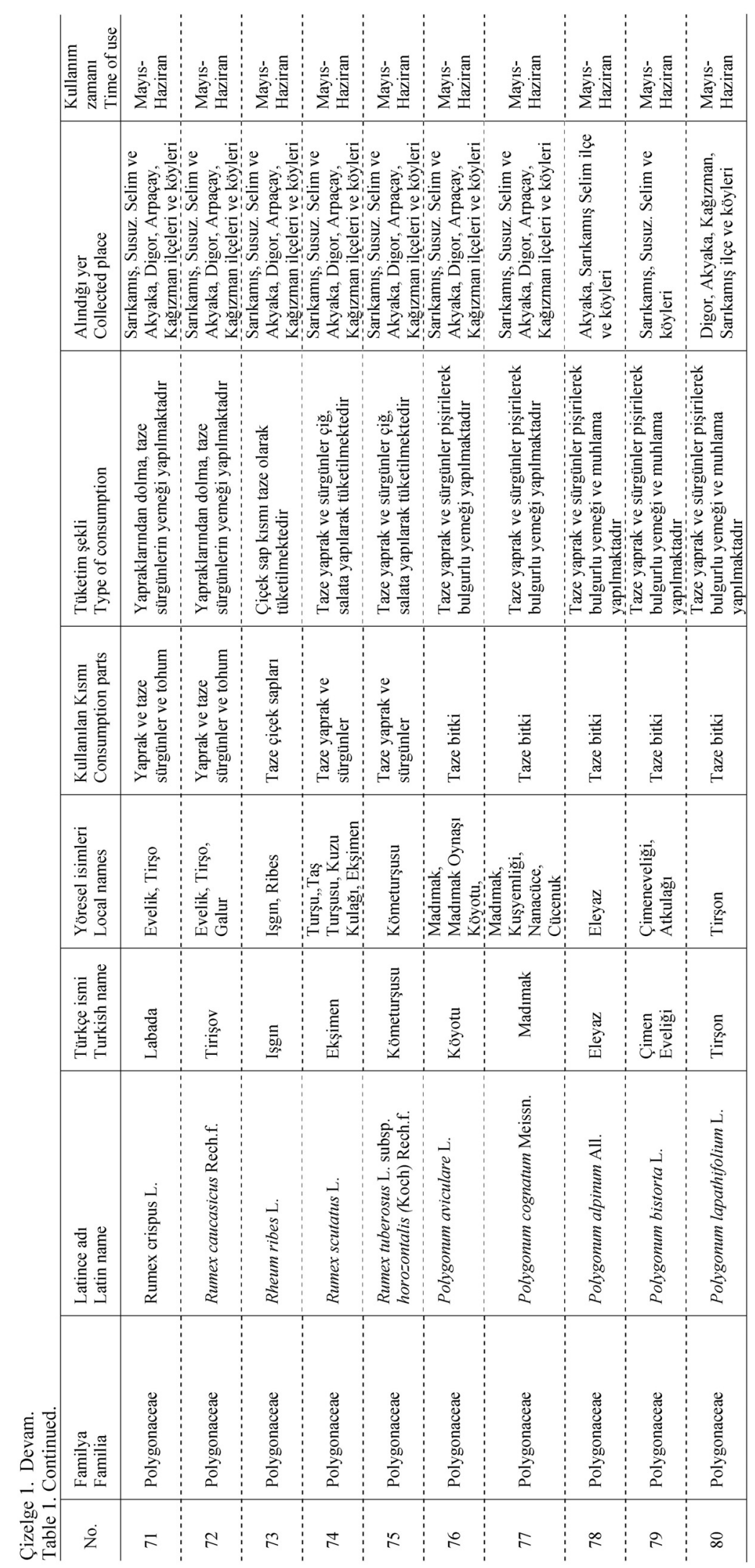




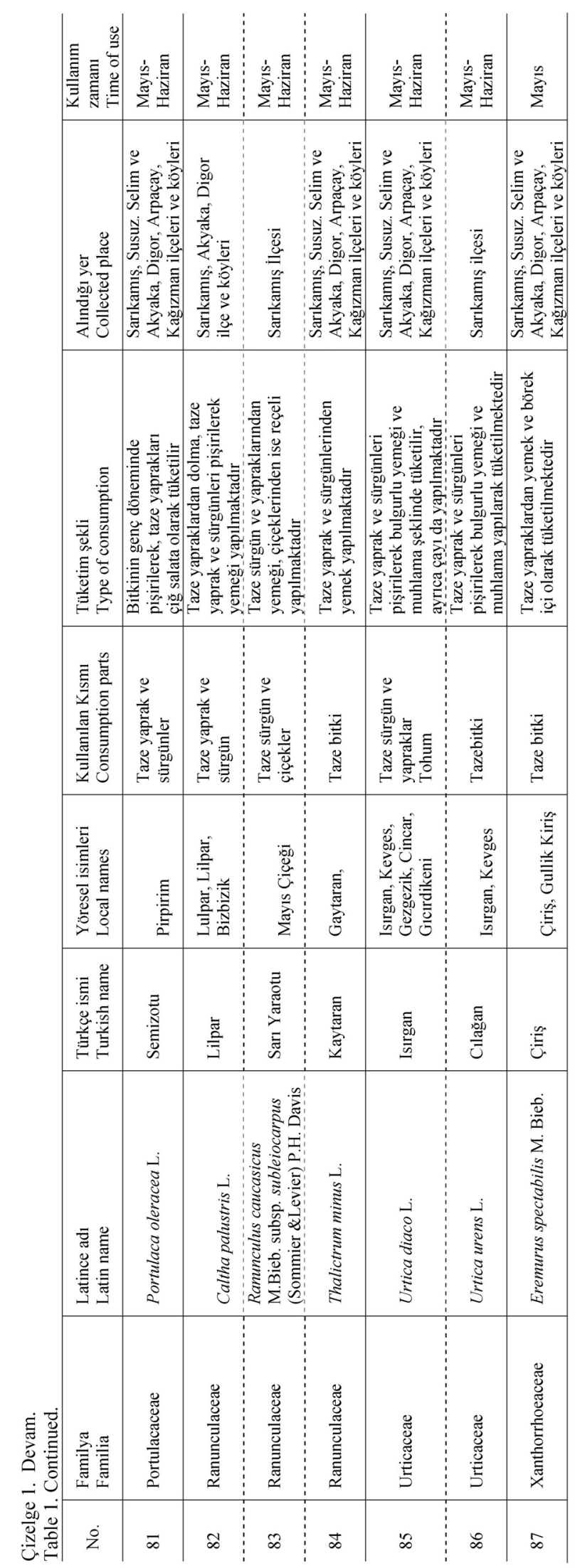


Nitekim, Samsun ve çevresinde doğada yetişen yabani bitkilerin, özellikle ilkbahar aylarında kırsal kesimde yaşayan insanlar tarafindan toplanarak pazara getirildiği, ayrıca son yıllarda doğal ve organik gıdalara karşı tüketicinin artan talebinin bu bitkilere olan ilgiyi artırdığı ve bu bitkilerin bir kısmının çiğ veya pişirilerek taze tüketilmesine olanak tanındığı, bir kısmının ise dondurularak, kurutularak, salamura veya konserveye işlenerek de tüketilebildiğini bildiren bulgularla sonuçlarımız benzerlik göstermektedir (Koca ve ark., 2011; Kadığlu ve ark., 2016).

Bulgularımıza göre bitki türlerinden Rumex, Polygonum, Chenopodium, Eremurus, Urtica, Malva ve Beta cinslerine ait türlerin yoğun bir şekilde çiğ ve pişirilerek tüketildiği, Allium ve Bellevalia cinslerine ait bazı türlerin ise peynir içine aroma vermesi için tercih edildikleri yöre halkı tarafindan belirtilmiştir. Ayrıca Ferula, Carum, Anthriscus ve Cherophyllum cinslerine ait bazı türlerinin salamura yapılarak turşu şeklinde tüketilmekte olduğu, öte yandan Salvia, Rumex ve Caltha cinsine ait olan bazı bitki türlerinin ise lorlu dolması yapılarak tercih edildiği görüşmelerle tespit edilmiştir. Özellikle araştırmaya konu olan bölgede yöre halkının Rumex crispus ve Rumex caucaisica türlerini salamura yaparak kışın yapraklarının dolma yapımında kullanıldığ 1 da belirlenmiştir. Bununla bereber, Rumex ve Plantago cinslerine ait bazı türlerin ise yazın kurutulup kışın değişik şekilde tüketiminin olduğu bildirilmiştir. Öte yandan Heracleum, Onopordum, Eryngium, Cirsium, Carduus ve Cardamine cinslerine ait bazı türlerin sadece taze sürgünlerin soyularak çiğ olarak tüketildiği, Tragopogon ve Scorozenera cinslerine ait türlerin ise ilde daha çok çiğ olarak tüketildiği tespit edilmiştir. Zira mevcut bulgularımız Erzurum'da sebze olarak değerlendirilen yöresel bazı bitki türlerini tespit etmek amacı ile yürütülen Güvenç ve Kaya (1996) çalışmasıyla benzerlik göstermektedir. Mevcut araştırma sonuçları incelendiğinde, Bağa yaprağ (Plantago major), 1sirgan (Urtica dioica), mananık (Sinapis arvensis), kuzukulağı (Rumex acotella), çaşır (Prangos uechritzii), 1şgın (Rheum ribes), çiriş (Asphodelus ramosus), kuşekmeği (Polygonum aviculare), yarpuz (Mentha pulegium), pirpirim (Portulaca oleracea) çaşır mantarı (Pleurotus eryngii) ve çayır mantarı (Agaricus campestris)'nın genellikle pişirilerek tüketildiği bulgularımızı destekler niteliktedir. Diğer taraftan çalışmamızla benzerlik ve farklılıkların bulunduğu, İyigün ve Özer (2001)'in Muş ili yöresinde yabanc1 ot türleri üzerinde yürüttükleri bir araştırmada; Eremurus spectabilis Bieb., Salvia sclarea L., Gundelia tournefortii L., Amaranthus retroflexus L., Urtica dioica L., Urtica urens L., Silene vulgaris (Moench) Garcke., Capsella bursapastoris (L.) Medik., Rumex crispus L., Mentha aguatica L., Portulaca oleracea L. türlerinin pişirilerek tüketildiği tespit edilmiştir.

Ayrıca Korkmaz ve Alpaslan (2014), Erzincan ili sınırları içerisinde yer alan Ergan Dağı çevresindeki köylerde yaşayan yöre halk1 tarafindan gida olarak kullanılan bitkilerin daha çok pişirilerek, taze sürgünlerinin soyularak çiğ, bazılarının ise salamura yapılarak tüketildiğini bu bitkilerin bazılarının, Chenepodium albüm (telotu), Chenepodium foliosum (yabaniçilek), Allium sintenisii (dağsarmısağı), Eryngium billardieri (eşekdikeni), Prangos ferulacea (çaşur), Prangos pabularia (holoz), Muscari coeleste (zağik), Eremurus spectabilis (Çiriş), Centaurea depresa (peygamberdüğmesi), Circium arvense (köygöçüren) olduğunu, Akgünlü (2012), Kilis ve Antep illerinde sebze olarak kullanılan bazı yabani bitki türlerinin Arum dioscorides (gavurpancarı), Chenopodium album (kazayağı), Malva sylvestris (ebegümeci), Mentha longifolia (yarpuz), Nasturtium officinale (su teresi), Papaver rhoeas (gelineli), Polygonum aviculare (kuşekmeği), Sinapis alba (hardal) ve Urtica dioica (1sirgan otu), pişirilerek tüketildiğini, Koca ve ark. (2011), Samsun ve çevresinde yabani olarak yetişen Aegopodium podagraria L. (mendek), Amaranthus retroflexus L. (horoz ibiği), Arum euxinum R.B. Mill. (nünük), Bellis perenis (papatya), Capsella bursa-pastoris (L.) Medik (çoban çantası), Chenopodium album L. (sirken), Coronopus squamatus (yolagelen) Falcaria vulgaris Bernh. (kazayağ1), Malva neglecta Wall. (ebegümeci), Mentha aquatica L. (su nanesi), Nasturdium officinale (su teresi), Ornithogalum sp. (çiğdem), Papaver rhoeas (gelincik), Polygonum cognatum Meissn. (madımak), Portulaca oleracea L. (semizotu), Rumex crispus L. (yazı pancarı), Rumex patientia L. (efelik), Silene vulgaris var. vulgaris (şakşak), Smilax excelsa L. (kırçan), 
Trachystemon orientalis L. (kaldırayak) ve Urtica dioica L. (1sırgan) türlerinin yoğun olarak tüketildiğini, bazı bitkilerin pişirilerek bazılarının ise baharat olarak kullanıldığını tespit etmişlerdir. Satil ve ark. (2007), Madra Dağı ve çevresinde gıda amaçlı kullanılan bitkilerin bazılarının pişirilerek bazılarının çiğ bazılarının ise baharat olarak kullanıldığını bu bitkilerin, Oenanthe pimpinelloide L. (alan maydanozu), Foeniculum vulgare Mill. (arapsaçı), Eryngium campestre L. (boğadikeni), Anethum graveolens L. (dereotu) Daucus carota L.( havuç), Sium sisarum L. var. lancifolium (Bieb.) Thell. (kazayağı), Petroselinum crispum (Mill.) Nyman ex. A.W.Hill (maydanoz), Cynara scolymus L. (enginar), Sonchus asper (L.) Hill subsp. glaucescens (Jord.) Ball. (elek helvas1), Lactuca sativa L. (marul) Taraxacum sp. (tatlihindiba), Cichorium intybus L. (acrhindiba), Armoracia rusticana Gaertn, B. Mey. \& Scherb. (eşekturpu) Nasturtium officinale R.BR. (gerdirme), Gerdeme Brassica oleraceae L. (lahana), Eruca sativa Mill. (roka), Lepidium sativum L. (tereotu), Raphanus raphanistrum L. (turpotu), Stellaria media (L.) Vill. (cicibücü), Spinacia oleracea L. (1spanak), Beta vulgaris (L.)Koch (pancar), Cucurbita pepo L. (kabak), Vicia faba L. (bakla), Vigna unguiculata (L.) Walp. (börülce), Ceratonia siliqua L. (keçiboynuzu), Castanea sativa Mill. (kestane), Asparagus acutifolius L. (tatlı filizotu), Malva neglecta Wallr. (develik) Morus nigra L. (dut), Papaver rhoeas L. (gelincik), Rumex acetosella L.( Kuzukulağı), Rumex patientia L. (labada), Prunus amygdalus Batsch (badem), Rubus sanctus Schreber (böğürtlen), Eriolobus trilobatus (Poir.) Roem. (dağelmas), Rosa canina L. (kuşburnu), Pyrus amygdaliformis Vill. (yabani ahlat), Celtis australis L. (çitlembik), Urtica dioica L. (1sırganotu) olduğunu bildirmişlerdir.

Korkmaz ve Karakurt (2015), Kelkit (Gümüşhane) yöresinde yaşayan halkın Eryngium billardieri gövdesinin kabuğunu soyarak yediğini, Pimpinella corymbosa'nın aroma vermesi için turşulara konulduğunu, Prangos pabularia kökünden turşu yapıldığını, gıda bozulmasını engellediği için peynire katıldığını, Arctium minus gövdesi tazeyken soyularak çiğ olarak yenildiğini, Centaurea depressa, çiçeklerinin baharat olarak kullanıldığını, Echinops orientalis kapitulumlarının temizlenip, geriye kalan yuvarlak reseptakulumun yenildiğini, Scorzonera tomentosa kökünün yer sakızı olarak çiğnendiğini, Tragopogon buphthalmoides var. Buphthalmoides'in çiğ yenildiğini, Asperugo procumbens yaprak ve gövdesinden yemek yapıldığını, Stellaria media subsp. media yapraklarından yemek yapıldığını, Astragalus gummifer kökünden çıkarılan yağa ekmek batırılarak yenildiğini, Quercus petraea meyvesinin yenildiğini bildirmiştir. Aksakal ve Yusuf (2008), Erzurum ili civarından Tragopogon aureus Boiss., Sambucus ebelus L. gibi bazı türlerin herhangi bir işleme tabi tutulmadan çiğ olarak tüketildiğini, 1sırgan gibi bazı bitkilerin ise hem çiğ hemde pişirilerek tüketildiğini, Antriscus nemerosa, Berberis crataegina ve Berberis vulgaris gibi bitkilerin ise sirke ve limon ile karıștırılarak salatalarda kullanıldı ğını bildirmiștir. Göğtepe ve ark. (2008), g1da olarak tespit edilen bitkilerin; Trogopogon porrifolius (Mircalık), Lathyrus tuberosus (kuşkonmaz), Rumex sp. (dırşo), Apia malabia (kelemenkeşir), Trogopogon aureus (yemlik), Ferula orientalis (çakşı), Arthemisia absinthium (süpürge otu), Plantago major (Belhevis), Capsella bursa (acigic1), Rumex potientia (evelik), Urtica dioica (1sirgan), Alliaria petiolata (dida), Heracleum pastinacifolium, (kabalak, devetaban1), Bellevolia sarmatica (kır çiçeği), Eryngium bilardieri (su dikeni), Chenopodium sp.(kazayağı), Vicia canescens (küllür), Salvia ceratopylla (öküz pöçüğü), Allium sp. (sirmo) gibi bitkilerin olduğunu bu bitki türlerinin pişirilerek, salata ve dolma yapılarak tüketildiği bildirilmiştir.

Mevcut bulgularımız ile önceki araştırma sonuçları arasında tespit edilen yabani bitki türlerinin kullanım şekilleri arasında benzerlik ve farklılıkların olduğu göze çarpmaktadır. Bu durumun nedeninin yöresel kültürlerin yaşam şekilleri ve bundan doğan farklılıklardan kaynaklandığı tahmin edilmektedir.

Özet olarak; ülkemizin köklü tarihi dikkate alındığında, gerek beslenme gerekse halk ilacı olarak bitkilerin kullanılmasının zengin bir geçmiși olduğu ve bu geleneğin kırsal kesimlerde halen sürdürüldüğü çalışma sonuçlarında görülmüştür. Bulgularımızda Kars ilinin kırsal kesimlerinde yaşayan insanlar tarafından birçok yabani bitki türünün toplanarak değişik şekillerde tüketildiği 
sonucuna varılmıştır. $\mathrm{Bu}$ bitkilerin birçoğunun orman veya açık arazilerde yabani olarak bulunduğu, çok az bir kısmının ise kırsal kesimde yaşayan insanlar tarafından yetiştirildiği tespit edilmiștir. Özellikle yerleşim yerlerinden uzakta, temiz alanlarda yetişen yenebilir bitkilerin doğal ve ilaçtan ari oluşları son yıllarda organik gıdalara olan ilginin artmasıyla önemli ölçüde değer

\section{LITERATÜR LISTESI}

Akan, H., M. M. Korkut ve M. M. Balos. 2008. Arat Dağ ve çevresinde (Birecik, Sanlıurfa) etnobotanik bir arastırma. Firat Üniv. Fen ve Müh. Bil. Dergisi 20 (1) 67-81.

Akgünlü, S. B. 2012. Kilis ve Gaziantep yöresinde tüketilen bazı yabani sebzelerin mineral içerikleri ve mikrobiyolojik analizler. Yüksek Lisans Tezi. Kilis 7 Aralık Üniversitesi Fen Bilimleri Enstitüsü Biyoloji Ana bilim Dalı.

Aksakal, Ö. ve K. Yusuf. 2008. Erzurum ve çevresinde halk tarafindan gida amaçlı olarak kullanılan bitkiler. s.1009-1012. Türkiye 10. Gıda Kongresi. 2008 Erzurum.

Alkayış, M. F. 2007. Türkiye Türkçesinde bitki adları. Doktora Tezi. Erciyes Üniversitesi, Sosyal Bilimler Enstitüsü, Kayseri.

Alpaslan, D. 2004. Van yöresinde doğal olarak yetişen bazı bitkilerin geleneksel tüketim şekilleri. Yüzüncü Y1 Alparslan, D. 1. Geleneksel Gidalar Sempozyumunun 23-24 Eylül, Van.

Altundağ, E., and N. Özhatay. 2008. Local Names Of Some Useful Plants From Iğdır Provınce (East Anatolıa). İstanbul Üniversitesi Eczacilık Fakültesi Dergisi 40: 101-116.

Altundağ, E., and M. Öztürk. 2011. Ethnomedicinal studies on the plant resources of east Anatolia, Turkey. Procedia Social and Behavioral Sciences 19: 756-777. https://doi.org/10.1016/j.sbspro.2011.05.195.

Baytop, T. 2007. Türkçe Bitki Adları Sözlügü. Türk Dil Kurumu, Üçüncü baskı, Ankara.

Davis, P. H. 1965-1985. Flora of Turkey and The East Aegean Islands. Vol. 1-9, Edinburgh University Press, Edinburgh.

Ece, S., Ç. Kızılarslan, E. Altundağ ve M. Akkaya. 2018. Biga'da (Çanakkale) geleneksel kullanımı olan bitkilerin yöresel adları ve adlandırma yaklaşımları. Avrasya Terim Dergisi 6 (1): 35-47.

Ekim, T., M. Koyuncu, M. Vural, H. Duman, Z. Aytaç ve N. Adıgüzel. 2000. Türkiye Bitkileri Kırmızı Kitabı (Eğrelti ve Tohumlu bitkiler). Türkiye Tabiatını Koruma Derneği, Ankara. kazanmıștır. Dolayısıyla sonraki araștırmalarda bu bitkilerin kültüre alınarak yetiştiriciliğgine başlanması ve bu değerli kaynaklardan yararlanılması teşvik edilmelidir. Böylece mevcut bitkilerin doğadan toplanarak yok olması önlenebilecek ve yetiştiriciliğini yapmak isteyen çiftçilere ek gelir kaynağı da sağlanabilecektir.

Engels, J. M. M. 2011. An introduction to plant germplasm exploration and collecting: planning, methods and procedures, follow-up. pp.1-6. In: Guarino L., V. R. Rao, and E. Goldberg (Eds.). Collecting Plant Genetic Diversity. Bioversity International. Rome, Italy.

Ertuğ, F. 2014a. Etnobotanik. s.318-344. A. Güner ve T. Ekim (Eds.). Resimli Türkiye Florası. Cilt 1. Türkiye İş Bankası Kültür Yayınları, Genel Yayın No: 390.

Ertuğ, F. 2014b. Yenen Bitkiler. s.345-380. A. Güner ve T. Ekim (Eds.). Resimli Türkiye Florası. Cilt 1. Türkiye İş Bankası Kültür Yayınları, Genel Yayın No: 390.

Göğtepe, S., N. Yaşar ve F. Güneş. 2008. Kars ve çevresinde yetişen bazı bitkilerin etnobotanik özellikleri. 19. Ulusal Biyoloji Kongresi. 23-27 Haziran Trabzon.

Güner, A. 2012. Türkiye Bittkiler Listesi (Damarlı Bitkiler) Kitabı, ANG Vakfi/ Nezahat Gökyiğit Botanik Bahçesi, Birinci basım Kasım 2012, İstanbul.

Güner, A., N. Özhatay, T. Ekim, and K. H. C. Başer. 2000. Flora of Turkey and The East Aegean Islands. Volume 11, Edinburgh University Press, Edinburgh.

Güneş, F., and N. Özhatay. 2011. An ethnobotanical study from Kars (Eastern) Turkey. Biological Diversity and Conservation ISSN 1308-8084 4/1: 30-41.

Güvenç, İ. ve Y. Kaya. 1996. Erzurum'da sebze olarak değerlendirilen yöresel bazı bitkiler. Atatürk Ünüversitesi Zir. Fak. Dergisi 27 (3): 369-374.

İyigün, Ö. ve Z. Özer. 2001. Muş ve yöresinde gıda olarak kullanılan yabancı otlar. Türkiye Herboloji Dergisi 4 (2): 66-73.

Kadıŏlu, S., G. Taşgın, B. Kadıŏlu, C. Karaman Gezenoğlu, S. Yüksel ve K. Karagöz. 2015. Halk Tarafindan Bilinen ve Değerlendirilen Bitki Genetik Kaynaklarının Belirlenmesi (Kop Geçidi). Sonuç Raporu. Doğu Anadolu Tarımsal Araştırma Enstitüsü, Erzurum.

Kadıŏlu, Z., K. Çukadar, A. Kandemir, M. Aslay, N. N. Kalkan, H. Vurgun ve N. Ertürk. 2016. Erzincan ve Erzurum illerinde sebze olarak tüketilen yabani bitki türlerinin tespiti ve kullanım şekilleri. Uluslararası Erzincan Sempozyumu. 28 Eylül-01 Ekim 2016. Erzincan. s. 855-877.

Kaval, İ., L. Behçet, and U. Cakilcioglu. 2014. Ethnobotanical study on medicinal plants in gecitli and its surrounding (Hakkâri-Turkey). Journal of Ethnopharmacology 155 (1): 171-184. 
Kendir, G. ve A. Güvenç. 2000. Türkiye'de yapılmış etnobotanik çalışmalara genel bir bakış. Hacettepe Üniversitesi Eczacıllk Fakültesi Dergisi 30 (1): 49.

Koca, İ., İ. Hasbay ve Ş. Bostanc1. 2011. Samsun ve çevresinde sebze olarak kullanılan bazı yabani bitkiler ve tüketim şekilleri. Samsun Sempozyumu. 13-16 Ekim 2011. Samsun

Korkmaz, M. ve Z. Alpaslan. 2014. Ergan dağı (ErzincanTürkiye)'nın etnobotanik özellikleri. Bağbahçe Bilim Dergisi 1 (3): 1-31. E-ISSN: 2148-4015.

Korkmaz, M. ve E. Karakurt. 2015. Kelkit (Gümüşhane) ilçesinde doğal gıda bitkilerinin geleneksel kullanımları. Biyoloji Bilimleri Araştırma Dergisi 8 (2): $31-39$.

Özgökçe, F., and F. Özçelik. 2004. Ethnobotanical aspects of some taxa in East Anatolia, Turkey. Economic Botany 58 (4): 697-704.

Satil, F. ve E. Akçiçek, S. Selvi. 2007. Madra dağı (Balıkesir/İzmir) ve çevresinde etnobotanik bir çalışma. Biyoloji Bilimleri Araştırma Dergisi 1 (1): 3136.
Şekeroğlu, N., F. Özkutlu, M. Deveci, Ö. Dede ve N.Yılmaz. 2005. Ordu yöresinde sebze olarak tüketilen bazı yabani bitkilerin besin değeri yönünden incelenmesi. Türkiye VI. Tarla Bitkileri Kongresi, Antalya. Cilt I, s. 523-528.

Tan, A., T. Taşkın ve A. İnal. 2013. Bitki Genetik Kaynaklarının Toplanması. Ege Tarımsal Araştırma Enstitüsü Yayınları. Teknik Broşür. No: 7. Güncellenmiş 3. basım. Menemen, İzmir.

Tan, A. ve T. Taşkın. 2013. Herbaryum Hazırlama Teknikleri. Ege Tarımsal Araştırma Enstitüsü Yayınları. Teknik Broșür No: 4. Güncellenmiş 3. basım. Menemen, İzmir.

Tekin, S. 2011. Üzümlü (Erzincan) ilçesinin etnobotanik özellikleri. Yüksek Lisans Tezi. Erzincan Binali Y1ldırım Ünüversitesi Fen Bilimleri Enstitüsü Biyoloji Ana Bilim Dalı. Erzincan.

Tuzlac1, E. 2011. Türkiye Bitkileri Sözlüğü (Genişletilmiş 2. Baskı). Alfa Yayınları, İstanbul.

Yapıcı, İ. Ü., H. Hoşgören ve Ö. Saya. 2009. Kurtalan (Siirt) ilçesinin etnobotanik özellikleri. Dicle Ünüversitesi Ziya Gökalp Eğitim Fakultesi Dergisi 12: 191-196.

Yeşil, Y. 2007. Kürecik bucağında etnobotanik bir çalışma. Yüksek Lisans Tezi. İstanbul Üniversitesi Sağlik Bilimleri Enstitüsü. 